\title{
Ensemble cloud-resolving modelling of a historic back-building mesoscale convective system over Liguria: the San Fruttuoso case of 1915
}

\author{
Antonio Parodi ${ }^{1}$, Luca Ferraris ${ }^{1,2}$, William Gallus ${ }^{3}$, Maurizio Maugeri ${ }^{4}$, Luca Molini ${ }^{1}$, Franco Siccardi ${ }^{1}$, and \\ Giorgio Boni ${ }^{1,2}$ \\ ${ }^{1}$ CIMA Research Foundation, Savona, Italy \\ ${ }^{2}$ Dipartimento di Informatica, Bioingegneria, Robotica e Ingegneria dei Sistemi, University of Genoa, 16145 Genoa, Italy \\ ${ }^{3}$ Department of Geological and Atmospheric Sciences, Iowa State University, Ames, Iowa, USA \\ ${ }^{4}$ Università degli Studi di Milano, Dipartimento di Fisica, Milan, Italy
}

Correspondence to: Antonio Parodi (antonio.parodi@cimafoundation.org)

Received: 29 September 2016 - Discussion started: 19 October 2016

Revised: 12 March 2017 - Accepted: 17 March 2017 - Published: 12 May 2017

\begin{abstract}
Highly localized and persistent back-building mesoscale convective systems represent one of the most dangerous flash-flood-producing storms in the north-western Mediterranean area. Substantial warming of the Mediterranean Sea in recent decades raises concerns over possible increases in frequency or intensity of these types of events as increased atmospheric temperatures generally support increases in water vapour content. However, analyses of the historical record do not provide a univocal answer, but these are likely affected by a lack of detailed observations for older events.

In the present study, 20th Century Reanalysis Project initial and boundary condition data in ensemble mode are used to address the feasibility of performing cloud-resolving simulations with $1 \mathrm{~km}$ horizontal grid spacing of a historic extreme event that occurred over Liguria: the San Fruttuoso case of 1915. The proposed approach focuses on the ensemble Weather Research and Forecasting (WRF) model runs that show strong convergence over the Ligurian Sea (17 out of 56 members) as these runs are the ones most likely to best simulate the event. It is found that these WRF runs generally do show wind and precipitation fields that are consistent with the occurrence of highly localized and persistent back-building mesoscale convective systems, although precipitation peak amounts are underestimated. Systematic small north-westward position errors with regard to the heaviest rain and strongest convergence areas imply that the reanalysis members may not be adequately representing the
\end{abstract}

amount of cool air over the Po Plain outflowing into the Ligurian Sea through the Apennines gap. Regarding the role of historical data sources, this study shows that in addition to reanalysis products, unconventional data, such as historical meteorological bulletins, newspapers, and even photographs, can be very valuable sources of knowledge in the reconstruction of past extreme events.

\section{Introduction}

Flash floods are phenomena very common to most Mediterranean coastal cities, accountable for millions of euros of damage and tens to hundreds of victims every year (Gaume et al., 2009). The north-western Mediterranean area is affected by such events in a period usually spanning from late summer (the end of August) to late fall (early December): in this period, the warm waters of the sea, in combination with large-scale meteorological systems coming from the Atlantic Ocean, provide a huge amount of energy, namely latent and sensible heat fluxes, to the atmosphere (Reale et al., 2001; Boni et al., 2006; Pinto et al., 2013). Heavy precipitation is then triggered by the typically very steep topography of the coasts: it frequently occurs that the monthly average rainfall falls intensely in just a few hours and/or a significant fraction (up to $30-40 \%$ ) of the yearly average falls in 1 day (Parodi et al., 2012; Fiori et al., 2014). Obviously, the losses experi- 
enced in terms of human lives and economic damage in these very densely populated areas are often dramatic.

Among the flash-flood-producing storms in the Mediterranean area, a prominent feature is the highly localized and persistent back-building of mesoscale convective systems (MCSs; Schumacher and Johnson, 2005; Duffourg et al., 2015; Violante et al., 2016). Such a scenario has often been observed in the last decade, when Liguria (NW Italy) and southern France have been repeatedly hit by severe floods: 2010 Varazze and Sestri Ponente, 2011 Cinque Terre and Genoa, 2012 Marseille and Isle du Levant, 2014 Genoa and Chiavari, 2015 Nice. As shown in several recent works (Parodi et al., 2012; Rebora et al., 2013; Fiori et al., 2014; Duffourg et al., 2015; Silvestro et al., 2015; Cassola et al., 2016; Silvestro et al., 2016), convective cells, embedded in such MCSs, are generated on the sea by the convergence of a warm and moist south-easterly flow and a northerly much colder and drier one. These structures are then advected to the land where the combined action of the aforementioned currents and the topography force them to persist for several hours over a very localized area (e.g. about $100 \mathrm{~km}^{2}$ ).

Many flood frequency studies have been carried out, focusing on rainfall regimes and Mediterranean flood seasonality and type (Barriendos et al., 2003; Llasat et al., 2005, 2014; Barriendos and Rodrigo, 2006; Boni et al., 2006; Pinto et al., 2013; Toreti et al., 2015). Due to the exploitation of both documentary sources and early measurements, these analyses have been able to go back several centuries; however, their results have been mostly inconclusive regarding changes in frequency of occurrence. Well-defined trends have not been found as usually flood frequency oscillates from period to period with no significant growth, not even in the most recent decades, regardless of the event's duration (a few hours to days).

The same result applies to precipitation extremes and their possible changes over the Mediterranean area in recent decades, studied by several authors, either by empirical or (mainly at-site) extreme value theory approaches (see e.g. Brunetti et al., 2001, 2004; Alpert et al., 2002; Kostopoulou and Jones, 2005; Moberg et al., 2006; Brunet et al., 2007; Kioutsioukis et al., 2010; Rodrigo, 2010; Toreti et al., 2010; van den Besselaar et al., 2013). The temporal tendencies are not fully coherent throughout the region (Ulbrich et al., 2012) and are conditioned rather by the specific site, the approach used and the period examined (Brugnara et al., 2012; Brunetti et al., 2012; Maugeri et al., 2015). Conversely, an increase in precipitation extremes over the Mediterranean area is generally indicated by climate model scenarios (Alpert et al., 2002; Giorgi and Lionello, 2008; Trenberth, 2011).

It is therefore still an open debate whether the frequency of these phenomena is really increasing or if it is merely the perception of both the general public and scientific community. The latter hypothesis is supported by the fact that in the last 10-20 years observational capabilities have substantially increased. For example, in Italy alone, the remotely automated weather station network has grown to 5000 stations, offering an average density of about $1 / 75$ station $\mathrm{km}^{-2}$ with a 1 to 10 min sampling rate. At the same time, the national weather radar network reached a fully operational coverage, allowing for direct evaluation of the space-time structure of precipitation (Rebora et al., 2013).

Another factor contributing to enhancement of the perception of an increasing frequency of extreme precipitation and floods is that it has become much easier for weather-related disasters to make it to the news (Pasquare and Oppizzi, 2012; Grasso and Crisci, 2016) and therefore to the general public. Moreover, rapidly growing population and soil consumption increase the exposure of the population to such phenomena (Ward et al., 2013; European Environmental Agency, 2015).

To better investigate whether extreme precipitation and flood frequency are really increasing in the Mediterranean, it is important to improve the exploitation of the information available from past meteorological data. A contribution to this improvement may come from the development of methods that identify which ensemble analyses from projects like the 20th Century Reanalysis Project are able to produce precipitation fields that are reasonably intense and capable of causing extreme floods.

This paper focuses on a case study with the aim of investigating the ability of cloud-resolving grid-spacing atmospheric simulations to capture the main features of an event causing a very severe flash flood. These simulations are performed using the Weather Research and Forecasting (WRF; Skamarock et al., 2008) numerical meteorological model forced by an ensemble of reanalysis fields from the 20th Century Reanalysis Project (Compo et al., 2006, 2011). The work is also important to reveal how well fine-scale models can simulate an event for which observations used to initialize the forcing model are extremely sparse (see Sect. 4). One prior work, Michaelis and Lackmann (2013), showed some promising results in the use of WRF for another historical event, the Great Blizzard of 1888 in New England, but that event was a mid-latitude cyclone driven by dynamics on a larger scale. More on the windstorm modelling, Stucki et al. (2015) reconstructed a 1925 high-impact foehn storm in the Swiss Alps.

In this study, the case under investigation was a very intense flash-flood-producing event that occurred in 1915 in eastern Liguria (20-25 km east of Genoa, Liguria region capital city), affecting San Fruttuoso, a small hamlet near Portofino, and the coastal cities of Santa Margherita Ligure, Rapallo and Chiavari (Fig. 1). Based on the newspapers of the time and documentary sources, after relatively light rain during the night between 24 and 25 September, in the early morning of 25 September, the area was hit for a few hours (07:00-11:00 UTC) by violent rain that triggered widespread flash flooding and a devastating debris flow. This landslide half demolished the San Fruttuoso 1000-year-old abbey and laid down a thick layer of sand and rocks to form a stillexisting $20 \mathrm{~m}$ wide $2 \mathrm{~m}$ deep beach (Faccini et al., 2009), 


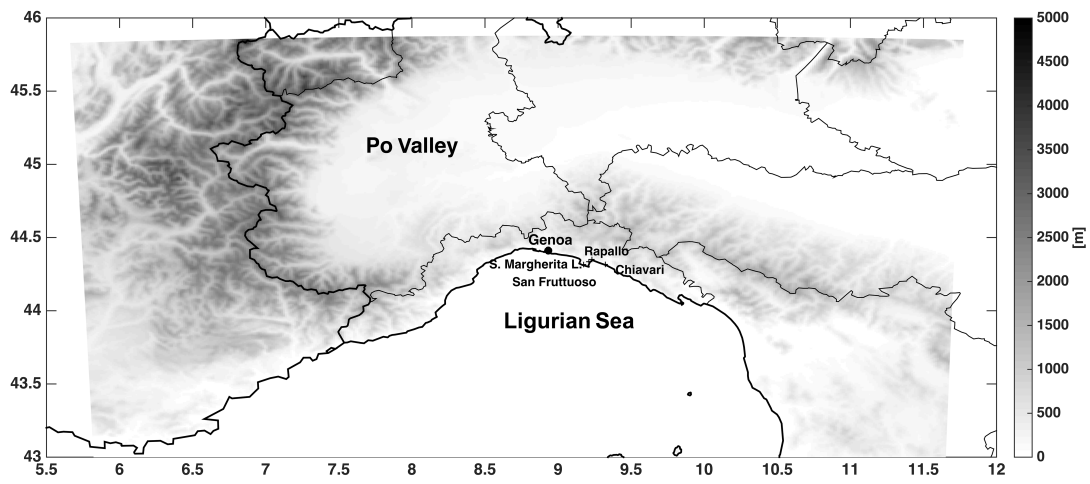

Figure 1. Study region and Liguria coastal cities affected by the September 1915 event.

today a very popular seaside resort. Based both on the observations of the time (wind speed and direction, rainfall, observed lightnings) available for north-western Italy, and on the model simulations, the occurrence of a back-building MCS is suggested.

The paper is organized as follows. In Sect. 2 the 1915 convective event is presented. Section 3 describes the WRF model setting performed. Results are discussed in Sect. 4. Conclusions are drawn in Sect. 5.

\section{Meteorological scenario}

The synoptic and mesoscale information for this event are available both from the 20th Century Reanalysis Project (Compo et al., 2006, 2011) and from the weather bulletins issued on a daily basis by the Italian Royal Central Office for Meteorology (Regio Ufficio Centrale di Meteorologia e Geodinamica).

The 20th Century Reanalysis Project is an effort led by the Earth System Research Laboratory (ESRL) Physical Sciences Division (PSD) of the National Oceanic and Atmospheric Administration (NOAA) and the Cooperative Institute for Research in Environmental Sciences (CIRES) at the University of Colorado to produce a reanalysis dataset covering the entire 20th century, assimilating only surface observations of synoptic pressure, monthly sea surface temperature and sea ice distribution. The observations have been assembled through international cooperation under the auspices of the Atmospheric Circulation Reconstructions over the Earth (ACRE) initiative and working groups of the Global Climate Observing System (GCOS) and World Climate Research Program (WCRP). The project uses an ensemble filter data assimilation method, which directly yields each sixhourly analysis as the most likely state of the global atmosphere, and it also gives estimates of the uncertainty in that analysis. This dataset provides the first estimates of global tropospheric variability spanning from 1851 to 2012, with a six-hourly temporal resolution and a $2.0^{\circ}$ grid spacing. This study adopts 20th Century Reanalysis Project ver- sion $2 \mathrm{C}$, which uses the same model as version 2 with new sea ice boundary conditions from the COBE-SST2 (Hirahara et al., 2014), new pentad Simple Ocean Data Assimilation with sparse input (SODAsi.2) sea surface temperature fields (Giese et al., 2016) and additional observations from ISPD version 3.2.9 (Whitaker et al., 2004; Compo et al., 2013; Krueger et al., 2013; Hirahara et al., 2014; Cram et al., 2015).

The weather bulletins issued by the Italian Royal Central Office for Meteorology include weather maps at 07:00 and 20:00 UTC and data (sea level pressure, wind direction and speed, temperature, cloud cover, cloud direction, state of the sea, weather of the past $24 \mathrm{~h}$ and notes) from about 125 Italian stations.

According to the reanalysis fields, the baroclinic circulation over Europe at 06:00 UTC on 25 September (i.e. a few hours before the most intense phase of the event) is quite typical for heavy precipitation events over the study area, with an upper-level trough over Great Britain leading to a diffluent flow over the Ligurian Sea area, in combination with a widespread high-pressure block over eastern Europe and southern Russia (Fig. 2a). The diffluent flow over the Ligurian Sea area is associated with warm air advection at $850 \mathrm{hPa}$ from the southern Mediterranean towards northern-western Mediterranean coastlines (Fig. 2b). Further information is provided by the mean sea level pressure (MSLP) field at the European scale: both the Italian weather map (07:00 UTC, Fig. 3b) and the reanalysis field (06:00 UTC, Figs. 2c and 3a) show an elongated trough over the western Mediterranean and a prominent ridge over southeastern Europe, representing a blocking condition on the large scale. The pressure gradient between the Gulf of Lyon and the northern Adriatic Sea is about $12 \mathrm{hPa}$, according to both Fig. 3a and $b$. The Italian weather map also gives evidence of a high-pressure ridge extending into the Po Valley, which causes a significant surface pressure gradient between the western part of the Po Valley and the Ligurian Sea (about $3 \mathrm{hpa}$ ), as well as between the eastern and the western parts of the Po Valley (about $4 \mathrm{hPa}$ ). This high-pressure ridge is present in the reanalysis MSLP field too (06:00 UTC, 


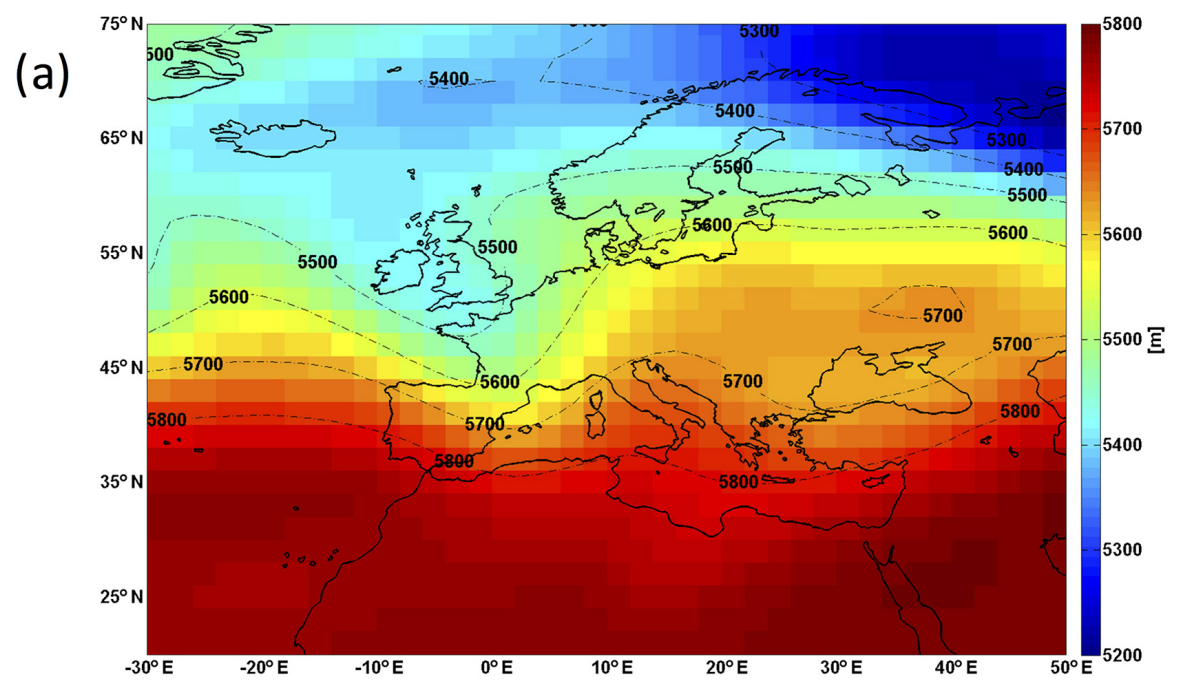

(b)

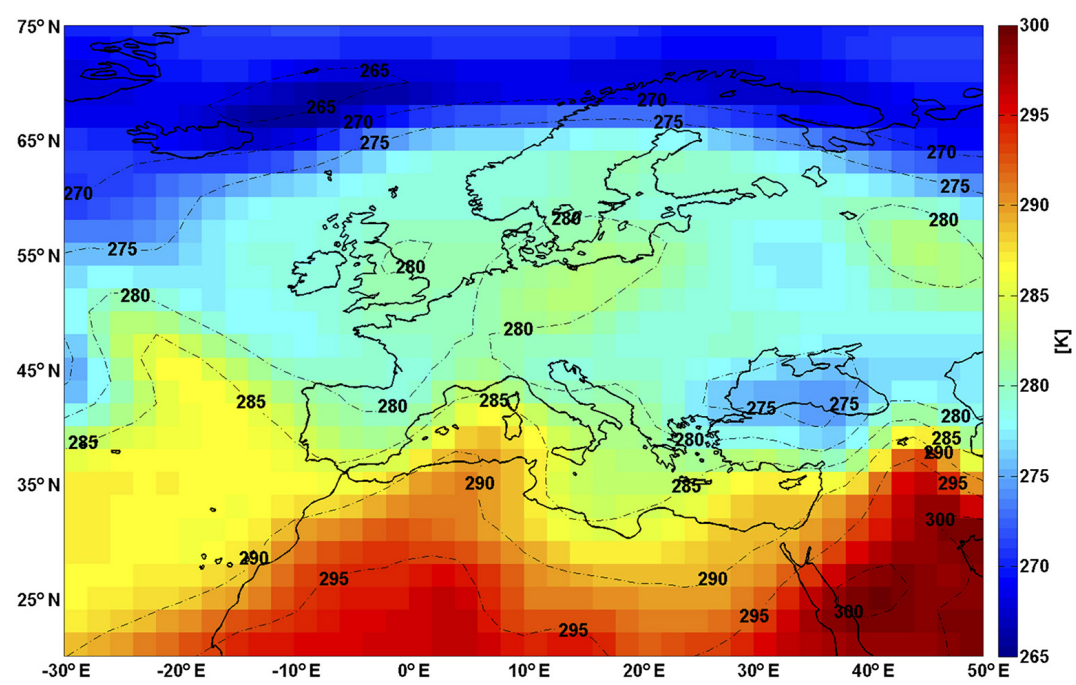

(c)

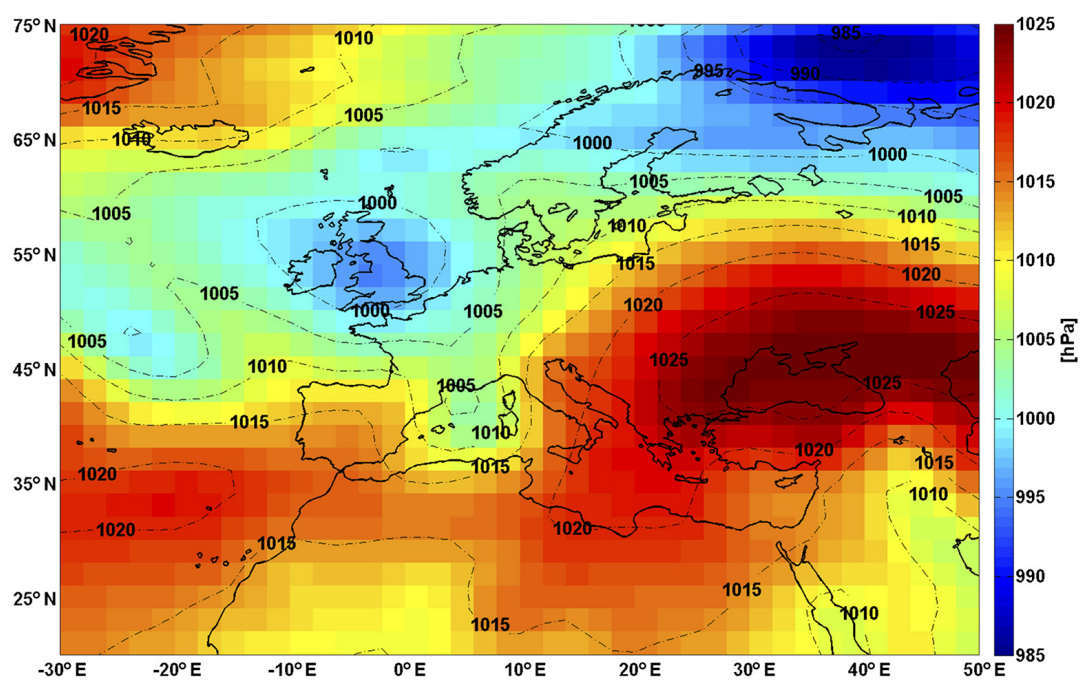

Figure 2. Image panels show the following: (a) $500 \mathrm{hPa}$ geopotential, (b) $850 \mathrm{hPa}$ temperature and (c) sea level pressure on $25 \mathrm{Septem}$ ber 1915 at 06:00 UTC (20th Century Reanalysis Project mean fields over the 56 ensemble members). 


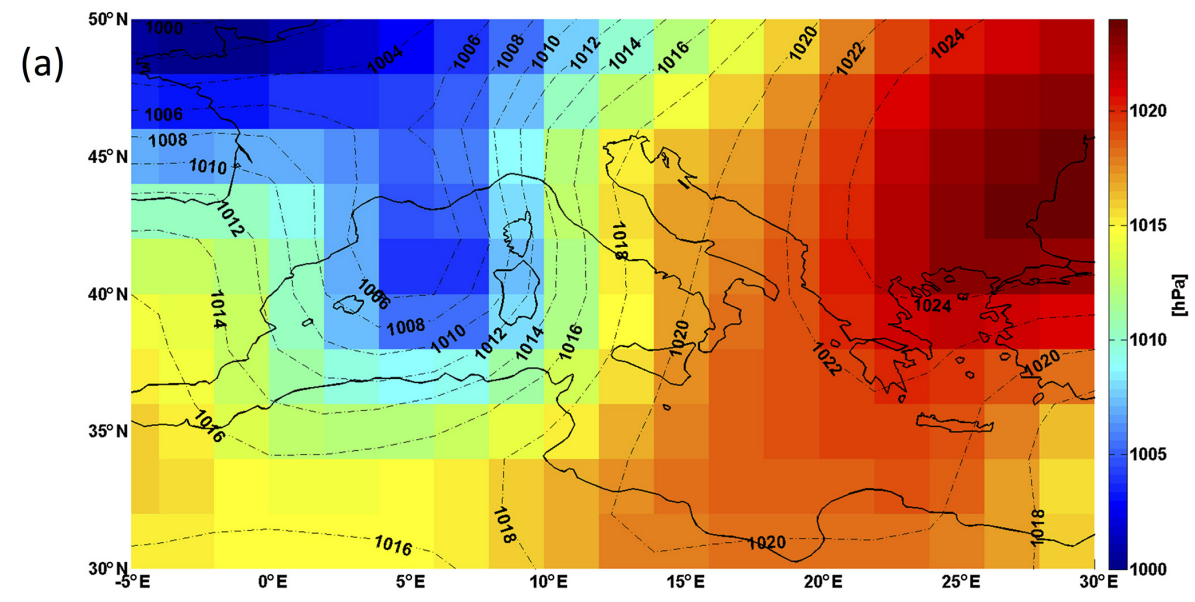

(b)

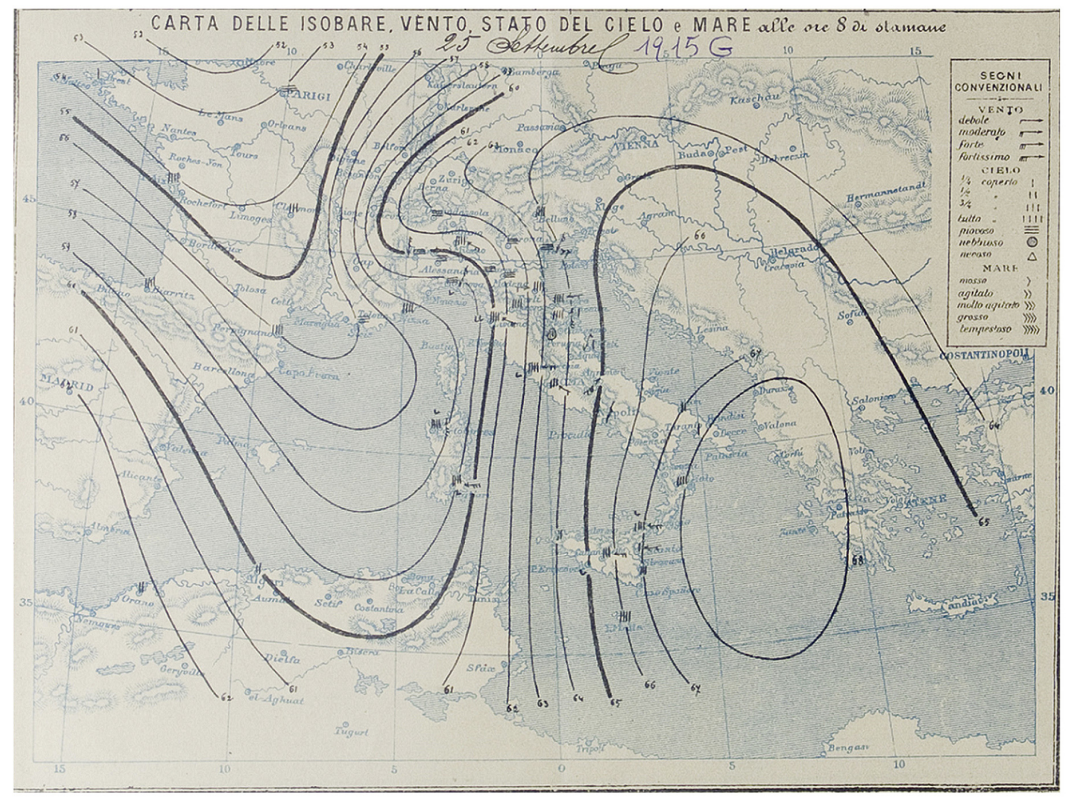

Figure 3. Panel (a) shows the same field as in Fig. 2c, but over the same area of the map in (b). Panel (b) shows sea level pressure isobars on 25 September 1915 at 07:00 UTC, as provided by the Italian Royal Meteorological Service.

Fig. 3a), even though it is much less evident than in the Italian weather map.

On the mesoscale, at 06:00 UTC, a significant $2 \mathrm{~m}$ temperature difference, around $3-4^{\circ} \mathrm{C}$, is apparent from 20 th Century Reanalysis Project fields between the Po Valley and the Ligurian Sea (Fig. 4a), as well as a significant $2 \mathrm{~m}$ specific humidity gradient (Fig. 4b). The temperature difference is also confirmed by the available observations at 07:00 UTC provided by the Italian Royal Central Office for Meteorology (Fig. 4c).

These mesoscale features represent the necessary ingredients for the generation of a back-building MCS offshore of the Liguria coastline, as observed in the 2010, 2011 and 2014 high-impact weather events in this region (Parodi et al., 2012; Rebora et al., 2013; Fiori et al., 2014).

The back-building MCS hypothesis is supported by the $48 \mathrm{~h}$ quantitative precipitation estimates (QPEs) for the period from 07:00 UTC 24 September to 07:00 UTC 26 September (Fig. 5). The rain gauges (64) contributing to this map have been provided by different datasets such as the European Climate Assessment \& Dataset project (Klein Tank et al., 2002; Klok and Klein Tank, 2009), the KNMI Climate Explorer dataset (Trouet and Van Oldenborgh, 2013), the Italian Meteorological Society (SMI; Auer et al., 2005), the Piedmont Region climatological dataset (Cortemiglia, 
(a)

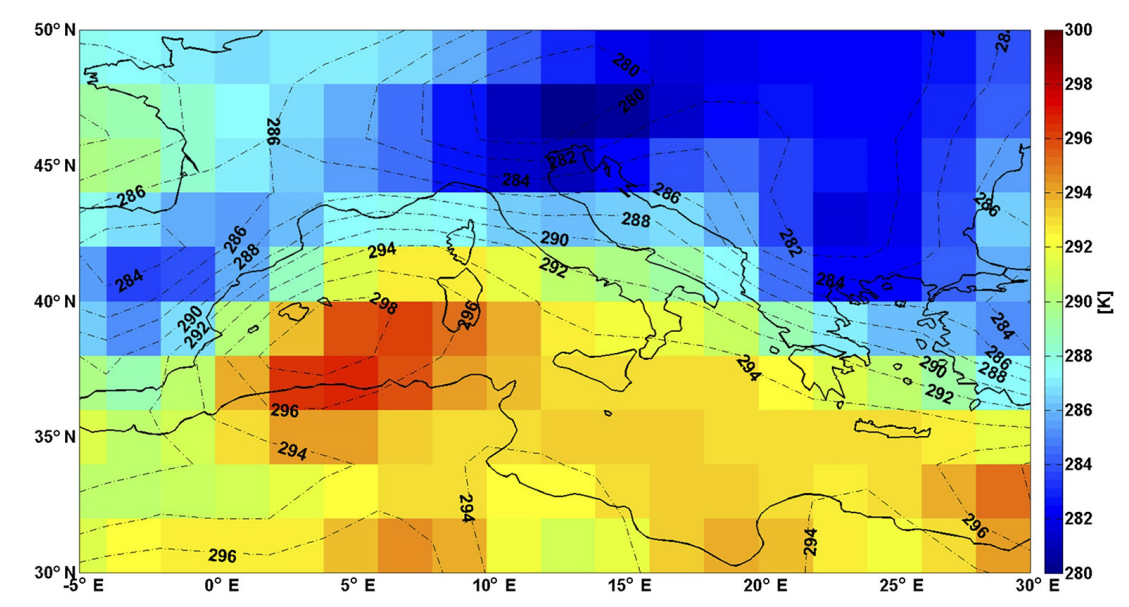

(b)

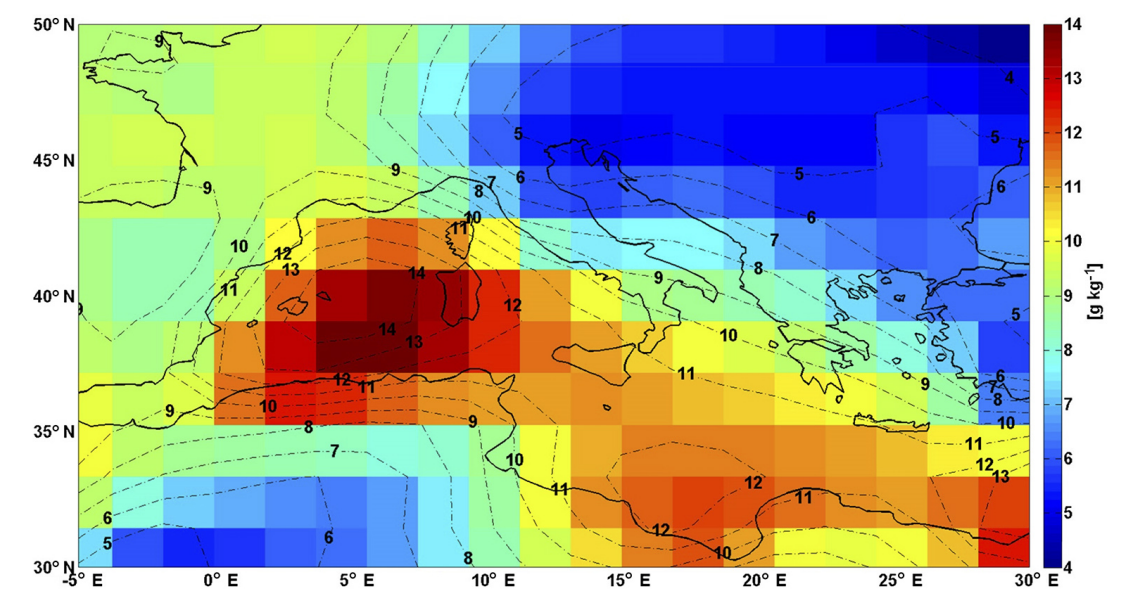

(c)

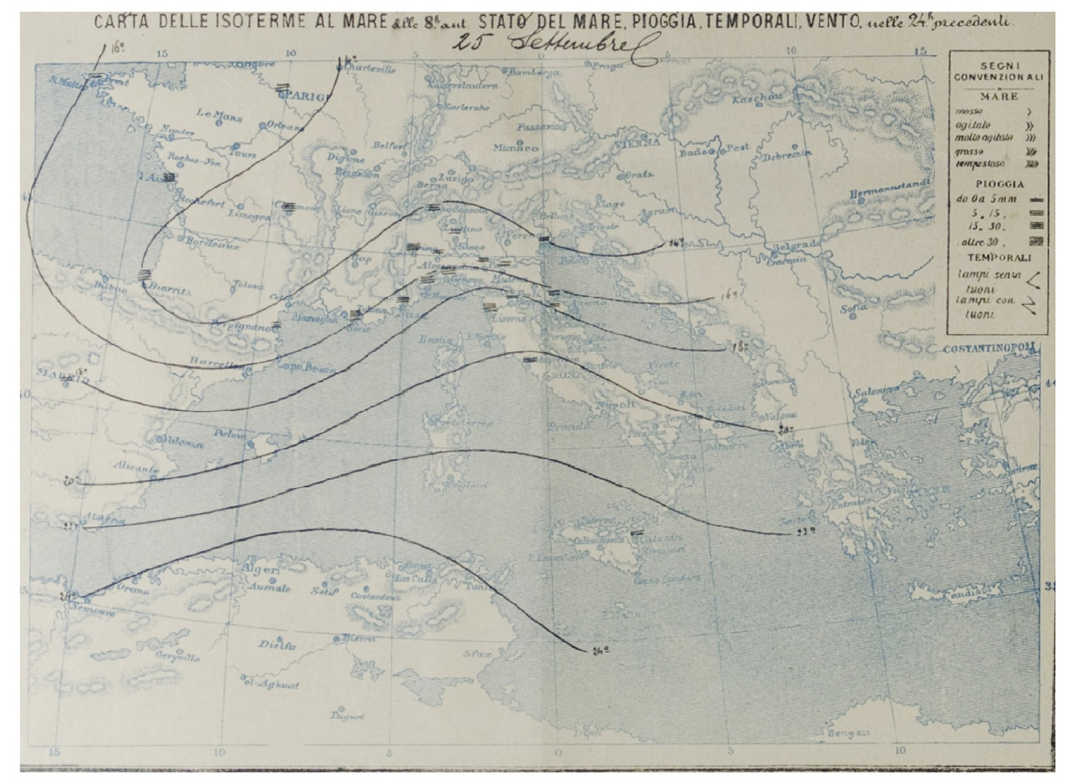

Figure 4. Panel (a) shows $2 \mathrm{~m}$ temperature and panel (b) shows $2 \mathrm{~m}$ specific humidity on 25 September 1915 (06:00 UTC) over the study region (20th Century Reanalysis mean fields over the 56 ensemble members). Panel (c) shows surface temperature isotherms on 25 September 1915 (07:00 UTC), as provided by the Italian Royal Meteorological Service. 


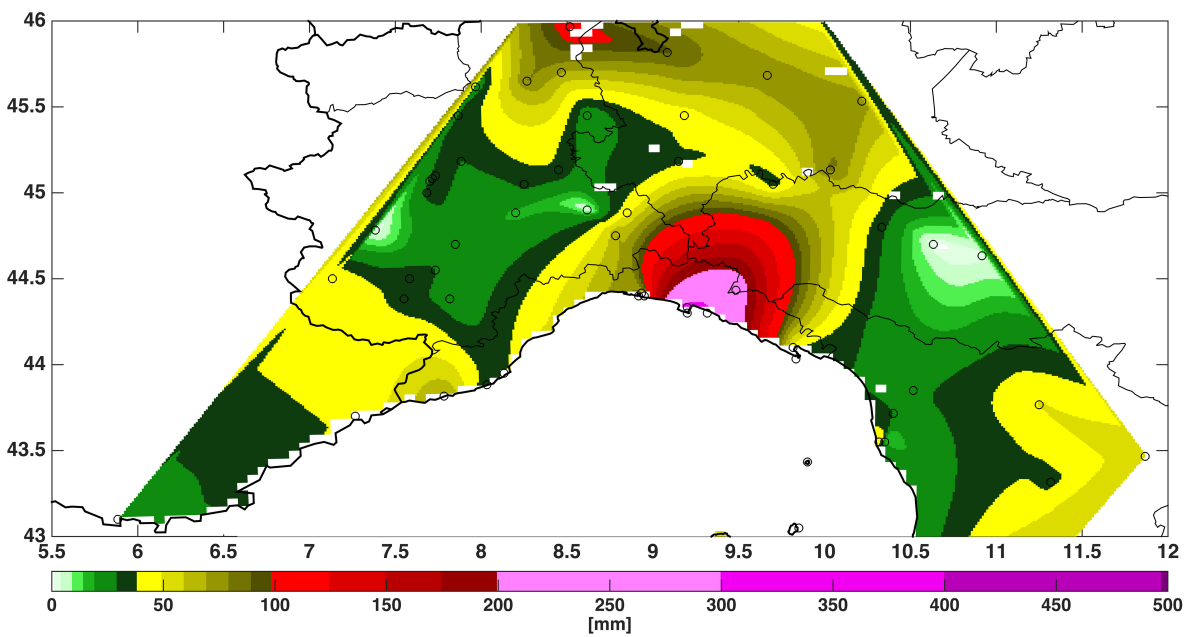

Figure 5. Quantitative precipitation estimates (QPEs) for 07:00 UTC 24 September-07:00 UTC 26 September 1915.

1999) and the Chiavari Meteorological Observatory (Ansaloni, 2006).

The QPE map clearly shows a v-shaped elongated pattern, very similar to the ones observed for the aforementioned events in Liguria. Based on historical information on sub-daily rain rates, it can be estimated that during the most intense phase of the event, the rainfall depths reached up to $400 \mathrm{~mm}$ in approximately $4 \mathrm{~h}$ (07:00-11:00 UTC on 25 September) in some rain gauges (Faccini et al., 2009). As a consequence of this intense and highly localized rainfall, the coastal cities of Rapallo, Santa Margherita Ligure, Chiavari and San Fruttuoso suffered very serious damages (Fig. 6), with a death toll of around 25-30 people. Interestingly, as in the case of the Genoa 2014 event, very intense lightning activity was documented by the Italian Royal Central Office for Meteorology (Fig. 7).

\section{ARW-WRF model simulations}

The model simulations have been performed using the Advanced Research Weather Research and Forecasting Model (hereafter as ARW-WRF, version 3.4.1). Initial and boundary conditions were provided by the 20th Century Reanalysis Project Version version 2c (Compo et al., 2006, 2011). The ARW-WRF model was applied for each of the 56 members of the ensemble provided by the 20th Century Reanalysis Project database.

The ARW-WRF model is configured for this case study based on the results achieved in the ARF-WRF modelling of the Genoa 2011 and Genoa 2014 v-shape convective structures (Fiori et al., 2014, 2017). Three nested domains (Fig. 8a), centred on the Liguria region, were used, with the outer nest d01 using $25 \mathrm{~km}$ horizontal grid spacing $(61 \times 55$ grid points), the middle nest $\mathrm{d} 02$ using $5 \mathrm{~km}$ grid spacing $(181 \times 201$ grid points $)$ and the innermost nest d03 using

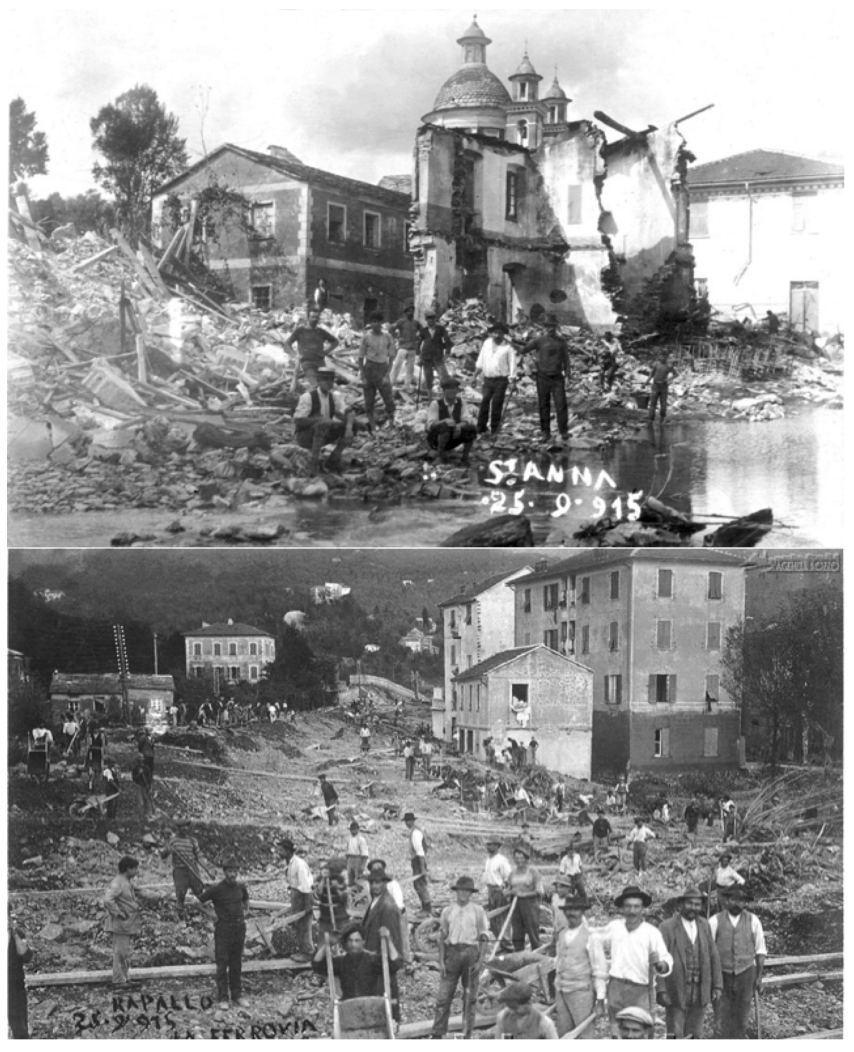

Figure 6. Rapallo flash-flood impacts on 25 September 1915 (courtesy of the real estate agency Bozzo in Camogli).

$1 \mathrm{~km}$ grid spacing ( $526 \times 526$ grid points). Figure $8 \mathrm{~b}-\mathrm{e}$ provide the comparison between the topography over the d03 area for $\mathrm{d} 01, \mathrm{~d} 02, \mathrm{~d} 03$ and the native $1 \mathrm{~km}$ grid spacing (for numerical stability reasons, given the very large number of ensemble members, initial conditions for $1 \mathrm{~km} \mathrm{d03}$ are interpolated from $5 \mathrm{~km} \mathrm{d02,} \mathrm{as} \mathrm{in} \mathrm{Fiori} \mathrm{et} \mathrm{al.,} \mathrm{2014).}$ 


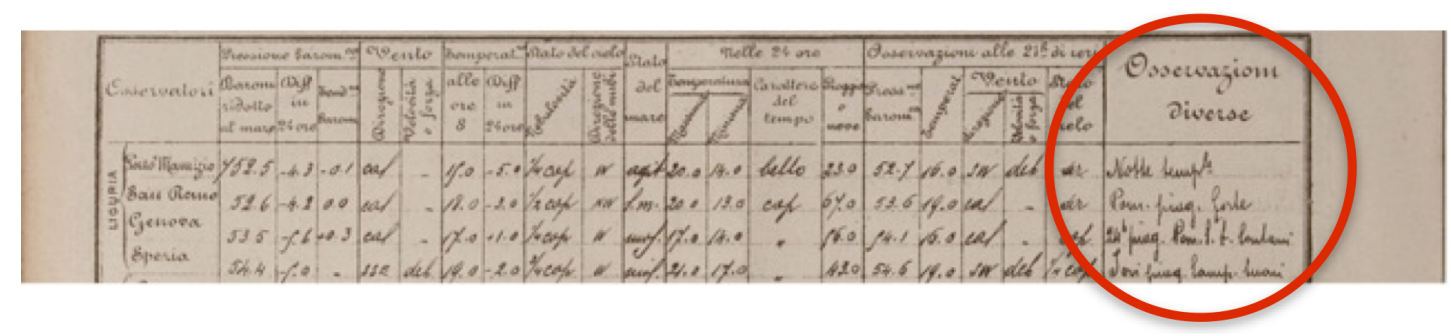

Figure 7. Thunderstorm and lightning activity reports (red circle) on 25 September 1915, as provided by the Italian Royal Meteorological Service.

The benefits of a high number of vertical levels have been demonstrated in Fiori et al. (2014), and thus the same higher number of vertical levels (84) is adopted in this study. Since the grid spacing ranges from the regional modelling limit $(25 \mathrm{~km})$ down to the cloud resolving one $(1 \mathrm{~km})$, two different strategies have been adopted with regard to convection parameterization. For domain d01 we adopted the new simplified Arakawa-Schubert scheme (Han and Pan, 2011) as it is also used by the 20th Century Reanalysis Project with $2.0^{\circ}$ grid spacing. Conversely, a completely explicit treatment of convective processes has been carried out on the $5 \mathrm{~km} \mathrm{d02}$ and $1 \mathrm{~km}$ d03 domains (Fiori et al., 2014).

The double-moment Thompson et al. (2008) scheme for microphysical processes has been adopted: this scheme takes into account ice species processes, whose relevance in this case study is confirmed by the intense lightning activity observed during the event, by explicitly modelling the spatiotemporal evolution of the intercept parameter $N_{i}$ for cloud ice. Furthermore, the Thompson scheme was shown to perform the best for the Genoa 2011 and Genoa 2014 studies (Fiori et al., 2014, 2017). With regard to the results in Fiori et al. (2014) about the role of the prescribed number of initial cloud droplets $-N t_{\mathrm{c}}-$ created upon autoconversion of water vapour to cloud water and directly connected to peak rainfall amounts, a maritime value corresponding to a $N t_{\mathrm{c}}$ of $25 \times 10^{6} \mathrm{~m}^{-3}$ has been adopted.

It is important to highlight that the availability of the 56 members ensemble is a key strength in the present study, which enables estimates of uncertainties associated with dynamical downscaling down to the ARF-WRF $1 \mathrm{~km} \mathrm{d03} \mathrm{do-}$ main.

\section{Results and discussion}

A fundamental ingredient for the occurrence of backbuilding MCSs is the presence of a persistent and robust convergence line: the availability of a large $1 \mathrm{~km}$ ARF-WRF dynamically downscaled ensemble (56 members) allows the exploration of how many members produce such a convergence line over the northern part of the Ligurian Sea region where most of such MCSs form (Rebora et al., 2013). A convergence line is classified here as persistent and robust if the minimum value of the divergence within the study area is less than $-7 \times 10^{-3} \mathrm{~s}^{-1}$ for at least $4 \mathrm{~h}$ in a row. The divergence threshold equal to $-7 \times 10^{-3} \mathrm{~s}^{-1}$ corresponds to the $99.95 \%$ percentile of the divergence values computed in every grid point within the region $7.50-10.25^{\circ} \mathrm{E}, 43.75-$ $44.50^{\circ} \mathrm{N}$, in Fig. 8 for each ensemble member in the period 12:00 UTC 24 September - 00:00 UTC 26 September (with a 30 min time resolution).

Using the threshold above, 17 of the 56 ARW-WRF runs ( $30 \%$ of the total) exhibit a persistent and robust convergence line in the considered period, while the remaining 39 do not produce it or it is not persistent. In particular, the time series of divergence for four members $(1,13,22$ and 37 respectively) show that the minimum is reached (Fig. 9) at approximately the same time when hourly QPF (quantitative precipitation forecast) exceeds $50 \mathrm{~mm} \mathrm{~h}^{-1}$ (Fig. 10a-d and g-1, members 1 and 13; Fig. 11a-d and g-1, members 22 and 37 ); the other 13 members are not shown as they behave very similarly. The four representative members also exhibit large QPFs over the whole $36 \mathrm{~h}$ of the simulations (Fig. 10f and n, members 1 and 13; Fig. 11f and n, members 22 and 37), even though significant differences both in the total amount and in the spatial distribution are found. Significant values of the Lightning Potential Index (LPI; Yair et al., 2010), in good agreement with the observations of the Italian Royal Central Office for Meteorology, are shown in Fig. 10 (panels e and m, members 1 and 13) and Fig. 11 (panels e and m, members 22 and 37).

However, most of the back-building MCS-producing members are affected by a non-negligible location error (see panels $f$ and $n$ of Figs. 10 and 11 for the four selected members) with respect to the observed daily rainfall map (Fig. 5). This feature is largely due to a predominance of the southeasterly wind component over the north-westerly one (coming from Po Valley), thus pushing the convergence line too far northwestwards (red dashed line), close to the western Liguria coastline. This discrepancy is explained by the highly localized spatio-temporal nature of this event, by the comparatively low spatial density of the surface pressure stations assimilated by the 20th Century Reanalysis Project over the western Mediterranean region (Fig. 12) and by the relatively coarse characteristics $\left(2.0^{\circ}\right.$ grid spacing, and 6-hourly tem- 
(a)
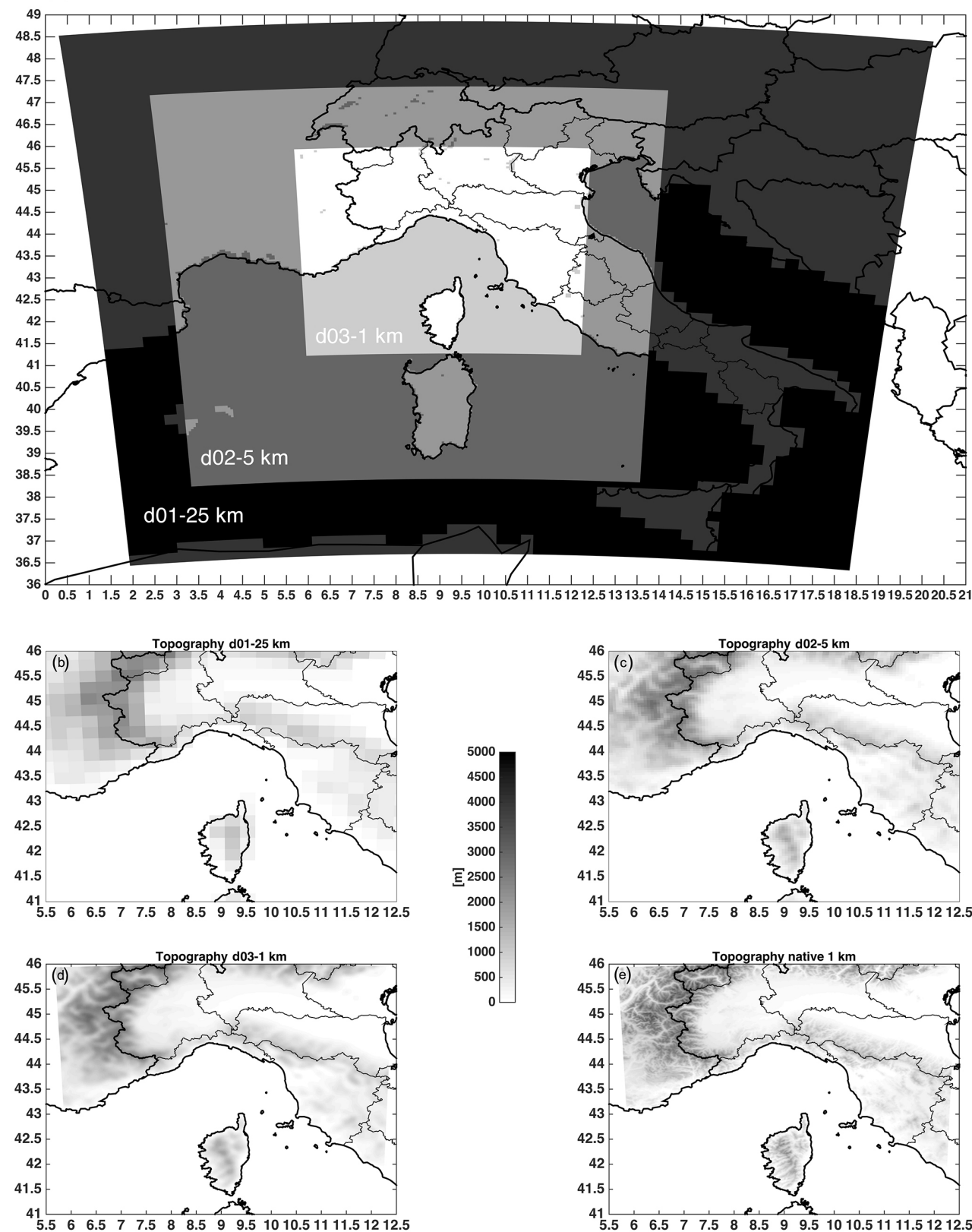

Figure 8. Panel (a) shows domains for the numerical simulations of the Genoa 1915 event, d01 $(\Delta=25 \mathrm{~km})$, d02 $(\Delta=5 \mathrm{~km})$ and d03 $(\Delta=1 \mathrm{~km}$ ). Panels (b-e) compare the topography over the $\mathrm{d} 03$ area for $\mathrm{d} 01, \mathrm{~d} 02, \mathrm{~d} 03$ and native $1 \mathrm{~km}$ grid spacing.

poral resolution) of the 20th Century Reanalysis Project forcing initial and boundary condition data. For instance, the primary wind convergence area over the sea and the inland area affected by the rainfall $\left(6.5-10.5^{\circ} \mathrm{E}, 43.5-45.5^{\circ} \mathrm{N}\right)$ is represented by only a few (two to three) 20th Century Reanalysis Project grid points.

To quantitatively examine precipitation errors for each ARW-WRF ensemble member, a bias and mean absolute error (MAE) analysis of the $36 \mathrm{~h}$ (12:00 UTC 24 September00:00 UTC 26 September) QPF versus the $48 \mathrm{~h}$ QPE
(07:00 UTC 24 September-07:00 UTC 26 September) is undertaken by comparing the available 64 rain gauges with the nearest grid points of the $1 \mathrm{~km} \mathrm{d03}$. The use of different time periods for QPE and QPF is not an issue as most of the observed precipitation reported for Liguria fell in a time span encompassed in the run time of the simulations. The results (Fig. 13) show that most of the 56 ARF-WRF members have a negative bias of roughly $10-40 \mathrm{~mm}$, largely explained by the widespread ensemble underestimation of the extreme rainfall depths over the coastal cities of Santa Margherita 

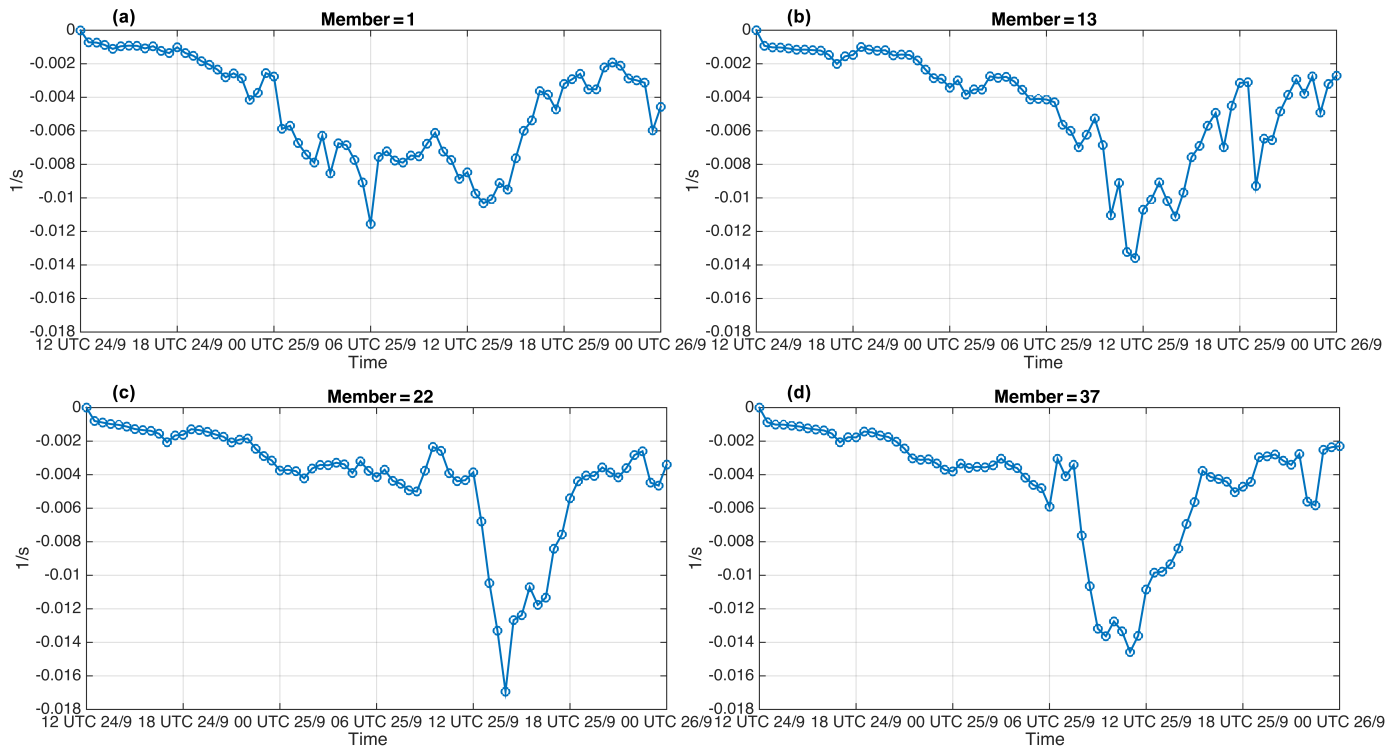

Figure 9. Minimum divergence time series (1/s) for members 1, 13, 22 and 37.
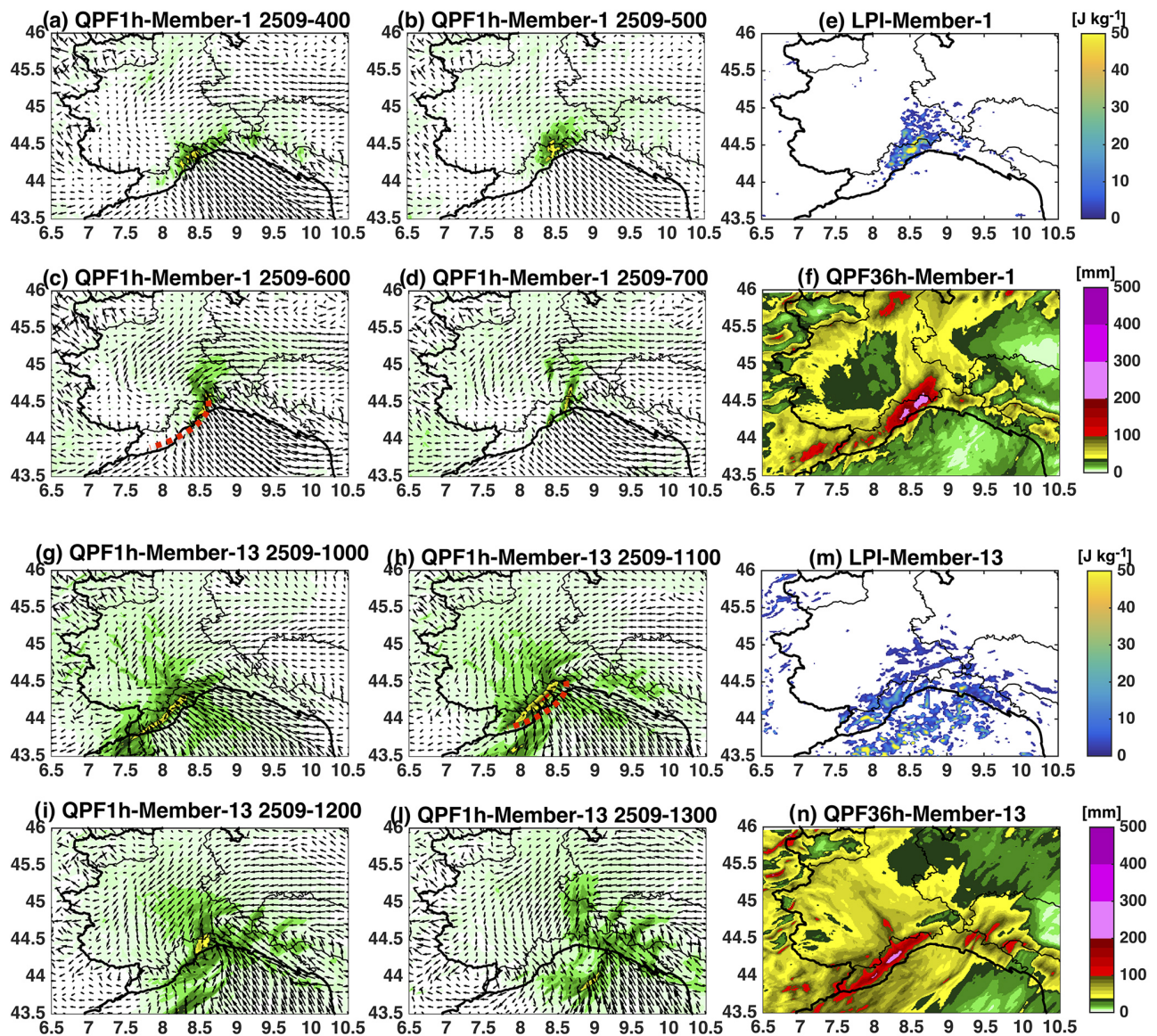

Figure 10. Panels (a-d) and (g-l) show the hourly QPF and $10 \mathrm{~m}$ wind fields corresponding to the period with the minimum divergence values in Fig. 9 for members 1 and 13 (the convergence line trace in the most active phase is red dashed). Panels (e-f) and (m-n) show the Lightning Potential Index accumulated over the same $4 \mathrm{~h}$ period and the $36 \mathrm{~h}$ QPF respectively for members 1 and 13. 

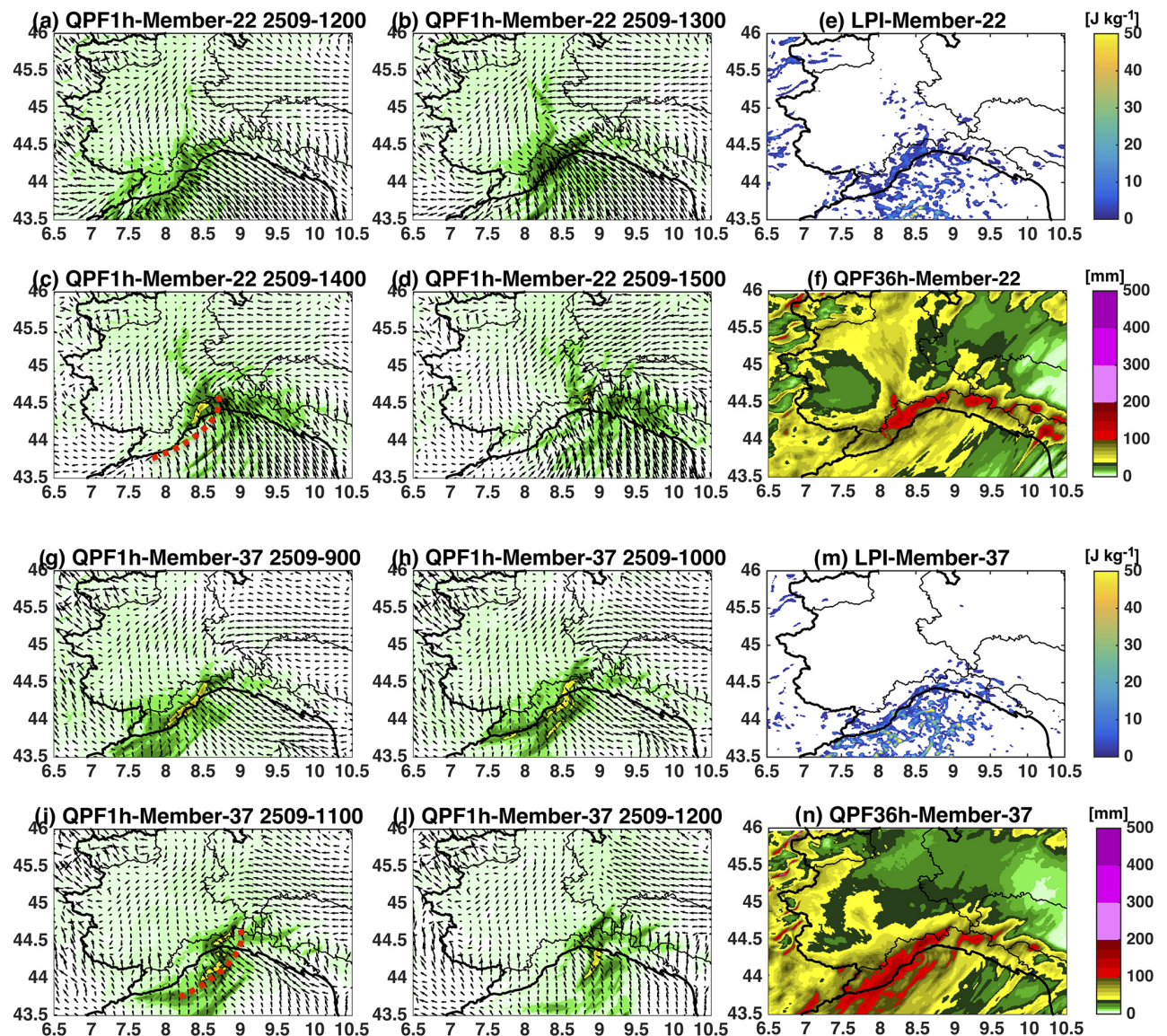

Figure 11. Panels (a-d) and (g-l) show the hourly QPF and $10 \mathrm{~m}$ wind fields corresponding to the period with the minimum divergence values in Fig. 9 for members 22 and 37 (the convergence line trace in the most active phase is red dashed). Panels (e-f) and (m-n) show the Lightning Potential Index accumulated over the same $4 \mathrm{~h}$ period and the $36 \mathrm{~h}$ QPF respectively for members 22 and 37.

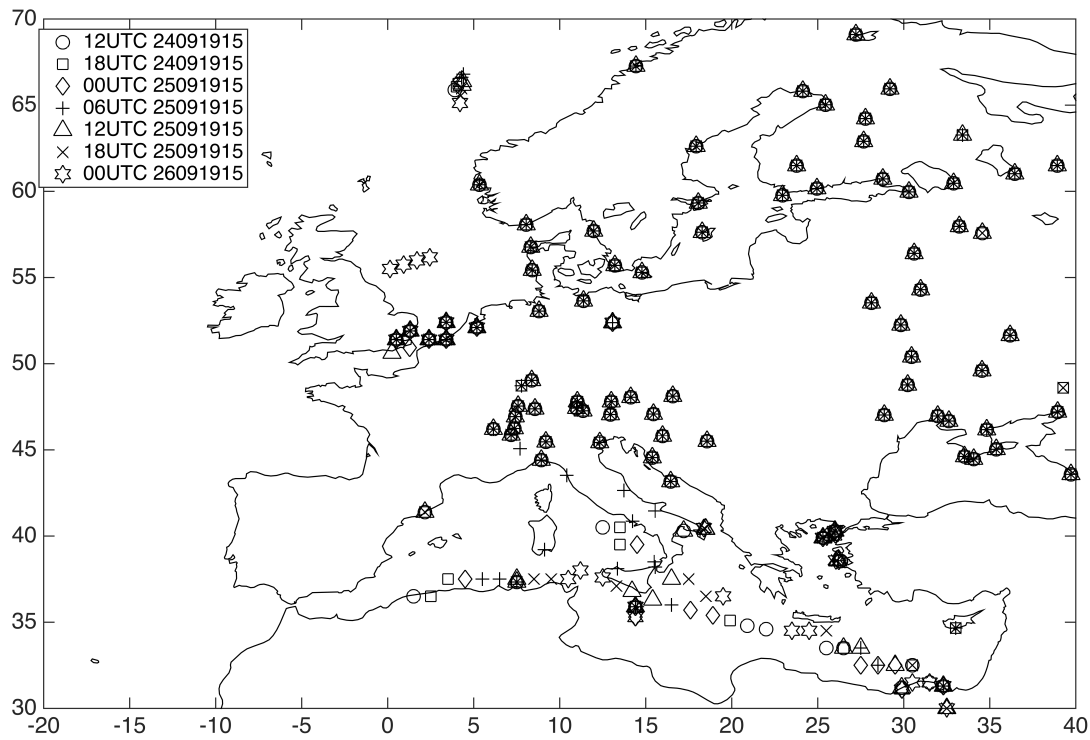

Figure 12. Surface pressure stations assimilated every $6 \mathrm{~h}$ in the period 12:00 UTC 24 September 1915-00:00 UTC 26 September 1915. 


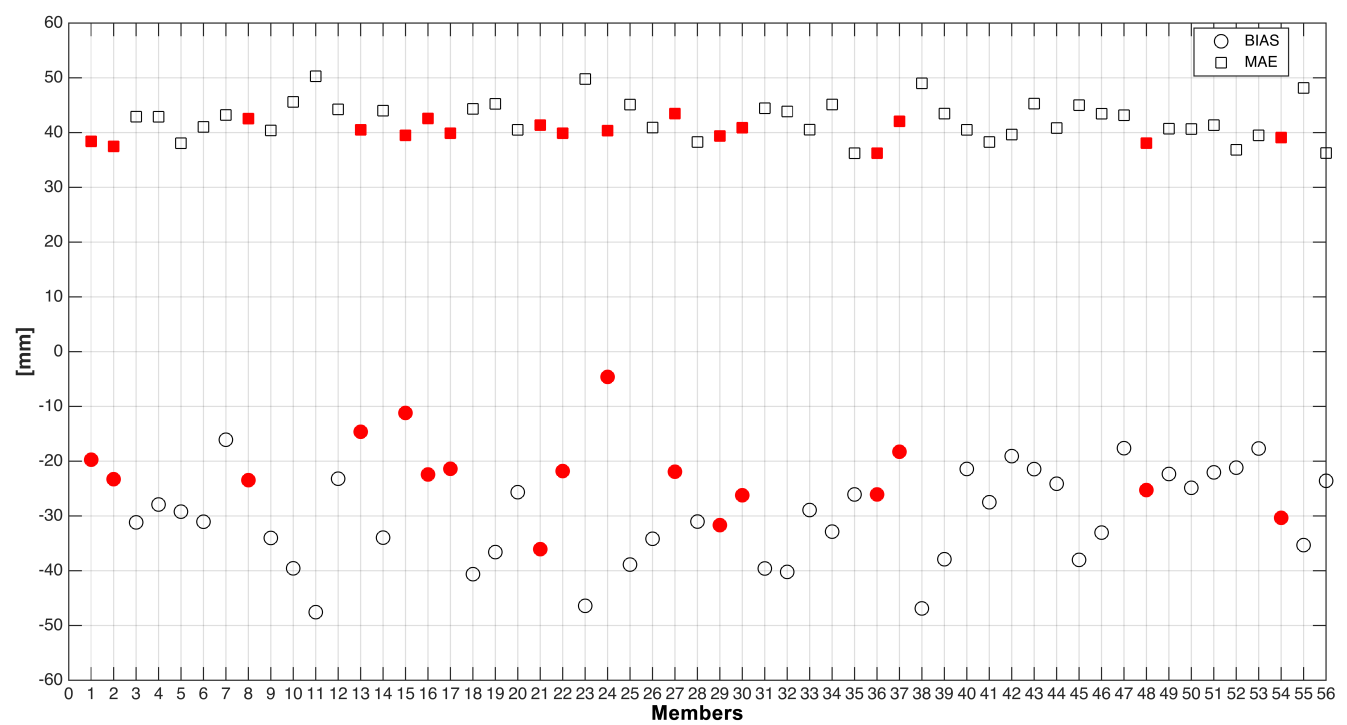

Figure 13. Rainfall depth bias and MAE for each $1 \mathrm{~km}$ d03 WRF member. Red markers represent the 17 members, producing robust and persisting convergence lines over the Ligurian Sea.

Table 1. Clusters pair statistics for the 12 members out of 17 , showing significant values (above 0.8 ) of the total interest function.

\begin{tabular}{lrr}
\hline Parameter & Average & $\begin{array}{r}\text { Standard } \\
\text { deviation }\end{array}$ \\
\hline Paired centroid distance $(\mathrm{km})$ & 114 & 62 \\
FCST area-obs area & 1.10 & 0.90 \\
FCST intensity 50-obs intensity 50 & 0.73 & 0.06 \\
FCST intensity 90-obs intensity 90 & 0.62 & 0.11 \\
\hline Total interest & 0.88 & 0.09 \\
\hline
\end{tabular}

Ligure, Rapallo and Chiavari. The 17 selected members (red markers) show an average bias of $-22 \mathrm{~mm}$ and a MAE of $40 \mathrm{~mm}$, while the remaining 39 members have an average bias of $-31 \mathrm{~mm}$ and a MAE of $42 \mathrm{~mm}$. Also for the $17 \mathrm{se}-$ lected members, the bias is largely explained by the stations mostly affected by the MCS, and it reduces to $-8 \mathrm{~mm}$ when Chiavari, Cervara Abbazia and S. Margherita Ligure are excluded from the comparison.

Because traditional verification measures (e.g. point-topoint verification measures) applied to QPF are greatly influenced by location errors (Mass et al., 2002), a deeper understanding of QPF performance in the WRF ensemble is gained by performing object-based verification using the method for object-based diagnostic evaluation (MODE; Davis et al., 2006a, b), intended to reproduce a human analyst's evaluation of the forecast performance. The MODE analysis is performed using a multi-step automated process. A convolution filter is applied to the raw field to identify the objects. When the objects are identified, some attributes regarding geometrical features of the objects (such as location, size, aspect ratio and complexity) and precipitation intensity (percentiles etc.) are computed. These attributes are used to merge objects within the same forecast and/or observation field to match forecast and observed objects and to summarize the performance of the forecast by attribute comparison. Finally, the interest value combines the attributes (the centroid distance, the boundary distance, the convex hull distance, the orientation angle difference, the object area ratio, the intersection divided by the union area ratio, the complexity ratio and the intensity ratio) computed in the object analysis in a total interest function, providing an indicator of the overall performance of matching and merging between observed and simulated objects. In the present study, the relative weight of each attribute used the default setting in MODE (National Center for Atmospheric Research; NCAR, 2013). The displacement errors including centroid distance and boundary distance were weighted the greatest in the calculation of total interest.

In our experiment we have empirically chosen the convolution disk radius and convolution threshold, so that this choice would recognize precipitation areas (at least roughly $50 \times 50 \mathrm{~km}$ or so) similar to what a human would identify. For each ARF-WRF ensemble member, the $36 \mathrm{~h}$ (12:00 UTC 24 September-00:00 UTC 26 September) QPF is compared with the 48h QPE (07:00 UTC 24 September-07:00 UTC 26 September), both bilinearly interpolated to the same $10 \mathrm{~km}$ grid. This grid spacing represents a good compromise between the native $1 \mathrm{~km}$ ARF-WRF grid spacing and the $40 \mathrm{~km}$ average distance between the available 64 rain gauges. After a set of experiments, we fixed the value of the convolution radius to one grid point and the threshold of the convoluted field to $75 \mathrm{~mm}$. Selected using the minimum divergence criterion, 12 out of the 17 members show significant values 

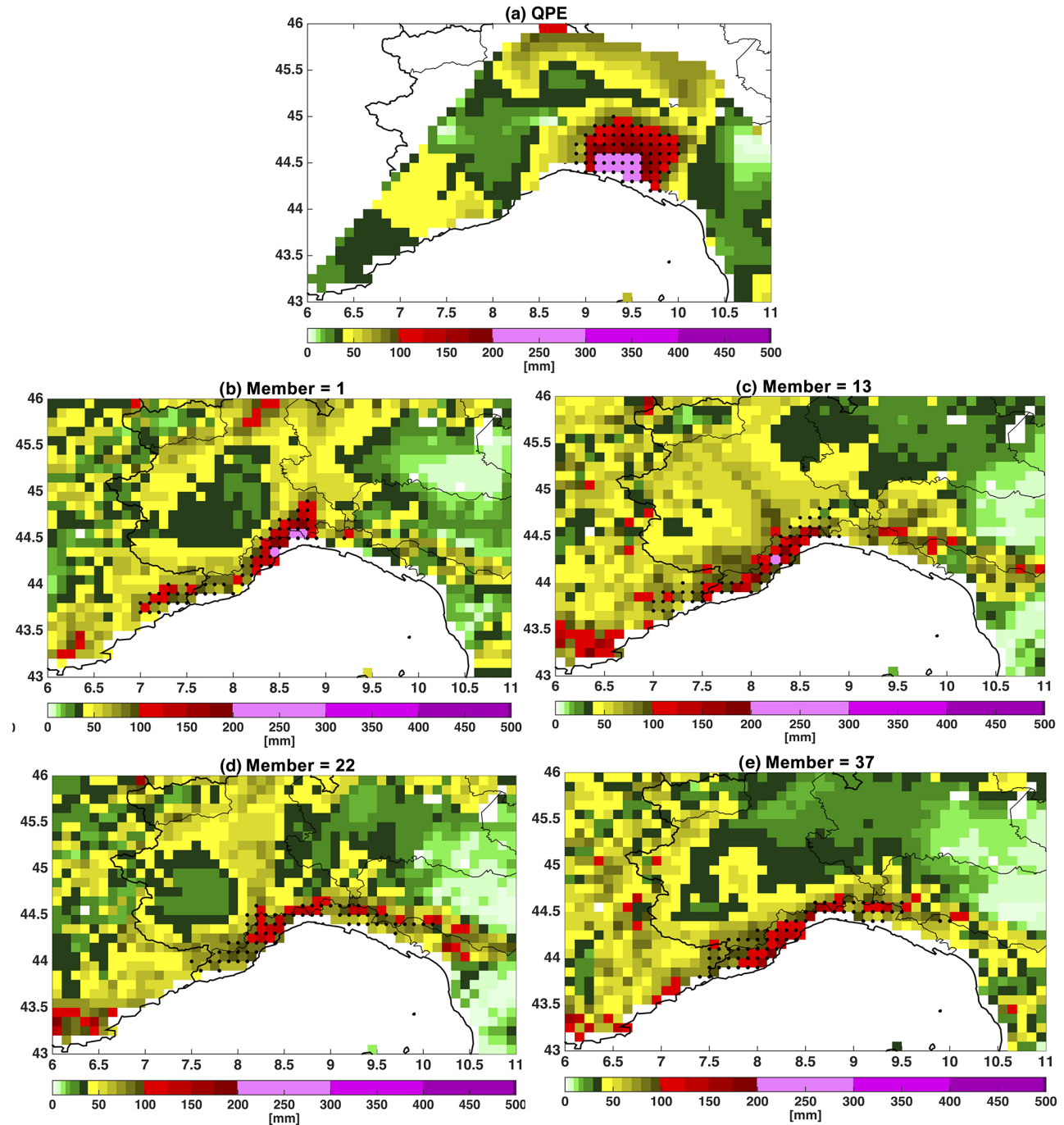

Figure 14. QPE regridded at $10 \mathrm{~km}$ grid spacing (a) and QPF from members 1 (b), 13 (c), 22 (d) and 37 (e), regridded at $10 \mathrm{~km}$ grid spacing (lower panels). Dots identify the areas of paired clusters.

(above 0.8 ) of the total interest function (Table 1). This value is slightly higher than the default one (0.7) used by MODE to match paired objects in order to restrict our analysis to the best-simulated events. Despite the limited observations available in 1915, our ensemble performs relatively well when considering object-based parameters. Specifically, when examining paired observed and modelled clusters, these 12 members demonstrate useful skill for centroid distance, providing a quantitative sense of spatial displacement of forecast; forecast area and/or observed area, providing an objective measure of over- or under-prediction of areal extent of the forecasts; forecast intensity 50-observed intensity 50 and forecast intensity 90-observed intensity 90, providing objective measures of median (50th percentile) and nearpeak (90th percentile) intensities found in the objects; and the already-mentioned total interest, a summary statistic de- rived from the fuzzy logic engine with user-defined interest maps for all these attributes plus others (Table 1).

Indeed it is impressive that small displacement errors averaging only $114 \mathrm{~km}$, with a standard displacement of only $62 \mathrm{~km}$, are obtained, despite the very crude initialization of a 1915 reanalysis case. In a much more recent set of cases, Duda and Gallus (2013) found an average displacement distance (absolute error) of $105 \mathrm{~km}$ for initiation of systems. Squitieri and Gallus (2016) show that centroids of forecasted MCSs in their sample of 31 relatively recent events in the US Great Plains are usually over $100 \mathrm{~km}$ or more removed from the centroids of the observed MCSs. Similarly good performance of the ensemble exists for areal coverage, rainfall intensity (although there is a 30-40\% underestimate) and overall characteristics of the forecasted objects as implied by the interest value. 

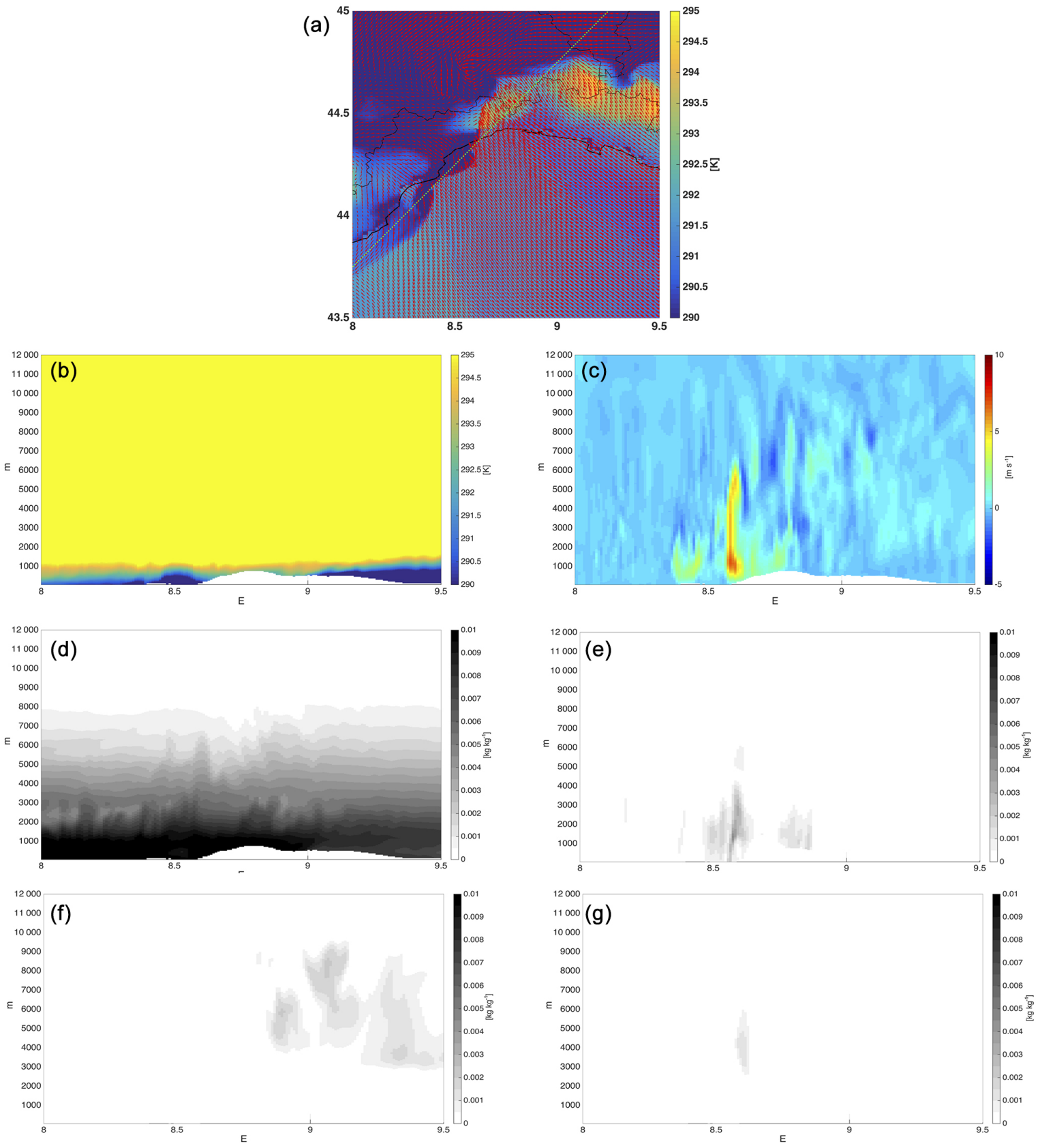

Figure 15. From member 1 at 06:00 UTC 25 September 2015, panel (a) shows $2 \mathrm{~m}$ potential temperature together with the $10 \mathrm{~m}$ horizontal wind vectors, while panels (b-g) show vertical cross sections of potential temperature, vertical velocity, water vapor, rain water, snow and graupel mixing ratios along the cross section (green dotted) shown in (a).

Selected members 1, 13, 22 and 37 (Fig. 14) have total interest values above 0.93 (close to 1 is good) and their paired clusters distance, namely the distance between centroids of observed and simulated rain regions, is around $100 \mathrm{~km}$.

The availability of high-resolution simulations allows one to gain a deeper understanding of the dynamics of the San Fruttuoso 1915 storm evolution. The physical mechanism responsible for the generation of the back-building mesoscale convective systems in this area has been recently explained by Fiori et al. (2017). Taking advantage of the availability of both observational data and modelling results at the micro$\alpha$ meteorological scale, Fiori et al. (2017) provide insights about the triggering mechanism and the subsequent spatiotemporal evolution of the Genoa 2014 back-building MCS. The major finding is the important effect of a virtual mountain created on the Ligurian sea by the convergence of a cold and dry jet outflowing from the Po Valley and a warm 
and moist low-level south-easterly jet within the planetary boundary layer.

The same mechanism is also active for this case. Let us consider as an example the convective flow field at 06:00 UTC on 25 September 1915 (see Fig. 15), as predicted by member 1 of the ensemble. Panel (a) shows the $2 \mathrm{~m}$ potential temperature field together with the $10 \mathrm{~m}$ horizontal wind vector field: the colder and drier jet outflowing from the Po Valley and the warmer and moister air from the southern Mediterranean Sea are evident. Panel (a) also shows, by means of the green dotted cross section $\left(45^{\circ}\right)$, the thin potential temperature layer (virtual mountain) in front of the actual Liguria topography (panel b). This acts, as described in Fiori et al. (2017), to produce strong convective cells in panel (c) (updraft velocity above $10 \mathrm{~m} \mathrm{~s}^{-1}$ ), with the apparent backbuilding on the western side (less mature and intense cells around $8.4^{\circ}$ latitude). The main updraft produces vertical advection of water vapour (panel d), thus resulting in significant production of rainwater (panel e), snow (panel f, significantly advected inland by the upper-level south-westerly winds) and graupel (panel g).

\section{Conclusions}

Highly localized and persistent back-building MCSs represent one of the most dangerous flash-flood-producing storms in the north-western Mediterranean area. A historic extreme precipitation event occurring over Liguria on September 1915, which seems to be due to one of these systems, was investigated in this paper by both means of a large collection of observational data and means of atmospheric simulations performed using the ARF-WRF model forced by an ensemble of reanalysis fields from the 20th Century Reanalysis Project.

The results show that the simulated circulation features are consistent with the hypothesis of a highly localized backbuilding MCS over the Ligurian Sea and that the ARF-WRF runs, driven by a significant fraction of the members of the 20th Century Reanalysis Project ensemble, produce fields that are in reasonable agreement with the observed data.

The proposed approach was to focus only on the ARFWRF runs showing strong convergence so as to get the best depiction of the event. Thus, we suggest that, when using datasets such as the 20th Century Reanalysis Project, it is important to consider that the physics-dynamics are likely to play a role in the events of interest and to follow a similar technique to selectively use the reanalysis ensemble members best displaying the key physics-dynamics of the event. Future work should further test an approach like this one to get a better understanding of how well the same convergence detection approach in regional climate model simulations of past and future climate (e.g. Pieri et al., 2015, at cloud-permitting grid spacing) can quantify possible changes in back-building MCS precipitation processes.
Concerning data collection, this study showed that in addition to the use of reanalysis products, other sources of data, such as newspapers, photographs and historical meteorological bulletins, can be essential sources of knowledge. Focusing on historical meteorological bulletins, future work on this particular case and similar ones occurring along the northwestern Mediterranean coastline will explore the use of bogus observations or other preprocessing techniques to alter lower-tropospheric conditions at model initialization time to better match actual observations, which may result in a better location of the convergence line and consequently simulation of the precipitation event.

Data availability. Data are available at TechnicalInfo (2017).

Competing interests. The authors declare that they have no conflict of interest.

Acknowledgements. This work was supported by the Italian Civil Protection Department and by the Regione Liguria. The ground-based observations were provided by the Italian Civil Protection Department and the Ligurian Environmental Agency. The rain gauge data were courtesy of the European Climate Assessment \& Dataset project, the KNMI Climate Explorer dataset, the Italian Meteorological Society, the Piedmont Region climatological dataset and the Chiavari Meteorological Observatory. Antonio Parodi would like also to acknowledge the support of the FP7 DRIHM (Distributed Research Infrastructure for Hydro-Meteorology, 2011-2015) project (contract number 283568). Thanks are due to CINECA, where the numerical simulations were performed on the Galileo System, project-ID: SCENE. W. Gallus appreciates the opportunity for a research visit at the University of Milan.

Edited by: S. Bronnimann

Reviewed by: two anonymous referees

\section{References}

Alpert, P., Ben-Gai, T., Baharad, A., Benjamini, Y., Yekutieli, D., Colacino, M., Diodato, L., Ramis, C., Homar, V., Romero, R., Michaelides, S., and Manes, A.: The paradoxical increase of Mediterranean extreme daily rainfall in spite of decrease in total values, Geophys. Res. Lett., 29, 31-1-31-4, doi:10.1029/2001GL013554, 2002.

Ansaloni, A.: The Observatory at Chiavari, Italy: its history and museum, Weather, 61, 283-285, 2006.

Auer, I., Boehm, R., Jurkovic, A., Orlik, A., Potzmann, R., Schoener, W., Ungersboeck, M., Brunetti, M., Nanni, T., Maugeri, M., Briffa, K., Jones, P., Efthymiadis, D., Mestre, O., Moisseline, J. M., Begert, M., Brazdil, R., Bochnicek, O., Cegnar, T., Garjic-Capka, M., Zaninovic, K., Majstorovic, Z., Szalai, S., Szentimery, T., and Mercalli, L.: A new instrumental Precipitation Dataset for the Greater Alpine Region for the period 1800 2002, Int. J. Climatol., 25, 139-166, 2005. 
Barriendos, M. and Rodrigo, F. S.: Study of historical flood events on Spanish rivers using documentary data, Hydrolog. Sci. J., 51, 765-783, 2006.

Barriendos, M., Coeur, D., Lang, M., Llasat, M. C., Naulet, R., Lemaitre, F., and Barrera, A.: Stationarity analysis of historical flood series in France and Spain (14th-20th centuries), Nat. Hazards Earth Syst. Sci., 3, 583-592, doi:10.5194/nhess-3-5832003, 2003.

Boni, G., Parodi, A., and Rudari, R.: Extreme rainfall events: Learning from raingauge time series, J. Hydrol., 327, 304-314, 2006.

Brugnara, Y., Brunetti, M., Maugeri, M., Nanni, T., and Simolo, C.: High-resolution analysis of daily precipitation trends in the central Alps over the last century, Int. J. Climatol., 32, 14061422, 2012.

Brunet, M., Jones, P. D., Sigró, J., Saladié, O., Aguilar, E., Moberg, A., Della-Marta, P. M., Lister, D., Walther, A., and López, D.: Temporal and spatial temperature variability and change over Spain during 1850-2005, J. Geophys. Res.-Atmos., 112, D12117, doi:10.1029/2006JD008249, 2007.

Brunetti, M., Maugeri, M., and Nanni, T.: Changes in total precipitation, rainy days and extreme events in northeastern Italy, Int. J. Climatol., 21, 861-871, 2001.

Brunetti, M., Buffoni, L., Mangianti, F., Maugeri, M., and Nanni, T.: Temperature, precipitation and extreme events during the last century in Italy, Global Planet. Change, 40, 141-149, 2004.

Brunetti, M., Caloiero, T., Coscarelli, R., Gullà, G., Nanni, T., and Simolo, C.: Precipitation variability and change in the Calabria region (Italy) from a high resolution daily dataset, Int. J. Climatol., 32, 57-73, 2012.

Cassola, F., Ferrari, F., Mazzino, A., and Miglietta, M. M.: The role of the sea on the flash floods events over Liguria (northwestern Italy), Geophys. Res. Lett., 43, 3534-3542, 2016.

Compo, G. P., Whitaker, J. S., and Sardeshmukh, P. D.: Feasibility of a 100-year reanalysis using only surface pressure data, B. Am. Meteorol. Soc., 87, 175-190, 2006.

Compo, G. P., Whitaker, J. S., Sardeshmukh, P. D., Matsui, N., Allan, R. J., Yin, X., Gleason Jr., B. E, Vose, R. S., Rutledge, G., Bessemoulin, P., Brönnimann, S., Brunet, M., Crouthamel, R. I., Grant, A. N., Groisman, P. Y., Jones, P. D., Kruk, M., Kruger, A. C., Marshall, G. J., Maugeri, M., Mok, H. Y., Nordli, Ø., Ross, T. F., Trigo, R. M., Wang, X. L., Woodruff, S. D., and Worley, S. J.: The twentieth century reanalysis project, Q. J. Roy. Meteor. Soc., 137, 1-28, 2011.

Compo, G. P., Sardeshmukh, P. D., Whitaker, J. S., Brohan, P., Jones, P. D., and McColl, C.: Independent confirmation of global land warming without the use of station temperatures, Geophys. Res. Lett., 40, 3170-3174, 2013.

Cortemiglia, G. C.: Serie climatiche ultracentenarie (con allegato CD ROM). Collana Studi Climatologici in Piemonte, Regione Piemonte, 3, 1-92, 1999.

Cram, T. A., Compo, G. P., Yin, X., Allan, R. J., McColl, C., Vose, R. S., Whitaker, J. S., Matsui, N., Ashcroft, L., Auchmann, R., Bessemoulin, P., Brandsma, T., Brohan, P., Brunet, M., Comeaux, J., Crouthamel, R., Gleason Jr., B. E., Groisman, P. Y., Hersbach, H., Jones, P. D., Jónsson, T., Jourdain, S., Kelly, G., Knapp, K. R., Kruger, A., Kubota, H., Lentini, G., Lorrey, A., Lott, N., Lubker, S. J., Luterbacher, J., Marshall, G. J., Maugeri, M., Mock, C. J., Mok, H. J., Nordli, O., Rodwell, M. J., Ross, T. F., Schuster, D., Srnec, L., Valente, M. A., Vizi, Z., Wang, X. L.,
Westcott, N., Woollen, J. S., and Worley, S. J.: The international surface pressure databank version 2, Geoscience Data Journal, 2, 31-46, 2015.

Davis, C., Brown, B., and Bullock, R.: Object-based verification of precipitation forecasts. Part I: Methods and application to mesoscale rain areas, Mon. Weather Rev., 134, 1772-1784, 2006a.

Davis, C., Brown, B., and Bullock, R.: Object-based verification of precipitation forecasts. Part II: Application to convective rain systems, Mon. Weather Rev., 134, 1785-1795, 2006b.

Duda, J. D. and Gallus Jr., W. A.: The Impact of Large-Scale Forcing on Skill of Simulated Convective Initiation and Upscale Evolution with Convection-Allowing Grid Spacings in the WRF*, Weather Forecast., 28, 994-1018, 2013.

Duffourg, F., Nuissier, O., Ducrocq, V., Flamant, C., Chazette, P., Delanoe, J., Doerenbecher, A., Fourrié, N., Di Girolamo, P., Lac, C., Legain, D., Martinet, M., Said, F., and Bock, O.: Offshore deep convection initiation and maintenance during I0P16a Offshore deep convection initiation and maintenance during HyMeX IOP 16a heavy precipitation event, Q. J. Roy. Meteor. Soc., 142, 259-274, 2015.

European Environmental Agency: SOER 2015 - The European environment - state and outlook 2015, A comprehensive assessment of the European environment's state, trends and prospects, in a global context, 2015.

Faccini, F., Piccazzo, M., and Robbiano, A.: Natural hazards in San Fruttuoso of Camogli (Portofino Park, Italy): a case study of a debris flow in a coastal environment, Bollettino della Societa $\mathrm{Ge}-$ ologica Italiana, 128, 641-654, 2009.

Fiori, E., Comellas, A., Molini, L., Rebora, N., Siccardi, F., Gochis, D. J., Tanelli, S., and Parodi, A.: Analysis and hindcast simulations of an extreme rainfall event in the Mediterranean area: The Genoa 2011 case, Atmos. Res., 138, 13-29, 2014.

Fiori, E., Ferraris, L., Molini, L., Siccardi, F., Kranzlmueller, D., and Parodi, A.: Triggering and evolution of a deep convective system in the Mediterranean Sea: modelling and observations at a very fine scale, Q. J. Roy. Meteor. Soc., 143, 927-941, doi:10.1002/qj.2977, 2017.

Gaume, E., Bain, V., Bernardara, P., Newinger, O., Barbuc, M., Bateman, A., Blaškovicová, L., Blöschl, G., Borga, M., Dumitrescu, A., Daliakopoulos, J., Garcia, J., Irimescu, A., Kohnova, S., Koutroulis, A., Marchi, L., Matreata, S., Medina, V., Preciso, E., Sempere-Torres, D., Stancalie, G., Szolgay, J., Tsanis, J., Velascom, D., and Viglione, A.: A compilation of data on European flash floods, J. Hydrol., 367, 70-78, 2009.

Giese, B. S., Seidel, H. F., Compo, G. P., and Sardeshmukh, P. D.: An ensemble of ocean reanalyses for 1815-2013 with sparse observational input, J. Geophys. Res.-Oceans, 121, 6891-6910, 2016.

Giorgi, F. and Lionello, P.: Climate change projections for the Mediterranean region, Global Planet. Change, 63, 90-104, 2008.

Grasso, V. and Crisci, A.: Codified hashtags for weather warning on Twitter: an Italian case study, PLoS, 8, doi:10.1371/currents.dis.967e71514ecb92402eca3bdc9b789529, 2016.

Han, J. and Pan, H. L.: Revision of convection and vertical diffusion schemes in the NCEP global forecast system, Weather Forecast., 26, 520-533, 2011. 
Hirahara, S., Ishii, M., and Fukuda, Y.: Centennial-scale sea surface temperature analysis and its uncertainty, J. Climate, 27, 57-75, 2014.

Kioutsioukis, I., Melas, D., and Zerefos, C.: Statistical assessment of changes in climate extremes over Greece (1955-2002), Int. J. Climatol., 30, 1723-1737, 2010.

Klein Tank, A. M. G., Wijngaard, J. B., Können, G. P., Böhm, R., Demarée, G., Gocheva, A., Mileta M., Pashiardis, S., Hejkrlik, L., Kern-Hansen, C., Heino, R., Bessemoulin, P., MüllerWestmeier, G., Tzanakou, M., Szalai, S., Pálsdóttir, T., Fitzgerald, D., Rubin, S., Capaldo, M., Maugeri, M., Leitass, A., Bukantis, A., Aberfeld, R., van Engelen, A. F. V., Forland, E., Mietus, M., Coelho, F., Mares, C., Razuvaev, V., Nieplova, E., Cegnar, T., Antonio López, J., Dahlström, B., Moberg, A., Kirchhofer, W., Ceylan, A., Pachaliuk, O., Alexander, L. V., and Petrovic, P.: Daily dataset of 20th century surface air temperature and precipitation series for the European Climate Assessment, Int. J. Climatol., 22, 1441-1453, 2002.

Klok, E. J. and Klein Tank, A. M. G.: Updated and extended European dataset of daily climate observations, Int. J. Climatol., 29, 1182-1191, 2009.

Kostopoulou, E. and Jones, P. D.: Assessment of climate extremes in the Eastern Mediterranean, Meteorol. Atmos. Phys., 89, 69$85,2005$.

Krueger, O., Schenk, F., Feser, F., and Weisse, R.: Inconsistencies between long-term trends in storminess derived from the 20CR reanalysis and observations, J. Climate, 26, 868-874, 2013.

Llasat, M. C., Barriendos, M., Barrera, A., and Rigo, T.: Floods in Catalonia (NE Spain) since the 14th century. Climatological and meteorological aspects from historical documentary sources and old instrumental records, J. Hydrol., 313, 32-47, 2005.

Llasat, M. C., Marcos, R., Llasat-Botija, M., Gilabert, J., Turco, M., and Quintana-Seguí, P.: Flash flood evolution in North-Western Mediterranean, Atmos. Res., 149, 230-243, 2014.

Maugeri, M., Brunetti, M., Garzoglio, M., and Simolo, C.: Highresolution analysis of 1 day extreme precipitation in Sicily, Nat. Hazards Earth Syst. Sci., 15, 2347-2358, doi:10.5194/nhess-152347-2015, 2015.

Mass, C. F., Ovens, D., Westrick, K., and Colle, B. A.: Does increasing horizontal resolution produce more skillful forecasts?, B. Am. Meteorol. Soc., 83, 407-430, 2002.

Michaelis, A. C. and Lackmann, G. M.: Numerical modelling of a historic storm: Simulating the Blizzard of 1888, Geophys. Res. Lett., 40, 4092-4097, 2013.

Moberg, A., Jones, P. D., Lister, D., Alexander, W., Brunet, M., Jacobeit, J., Alexander, L. V., Della-Marta, P. M., Luterbacher, J., Yiou, P., Chen, D., Klein Tank, A. M. G., Saladié, O., Sigró, J., Aguilar, E., Alexandersson, H., Almarza, C., Auer, I., Barriendos, M., Begert, M., Bergström, H., Böhm, R., Butler, C. J., Caesar, J., Drebs, A., Founda, D., Gerstengarbe, F. W., Micela, G., Maugeri, M., Österle, H., Pandzic, K., Petrakis, M., Srnec, L., Tolasz, R., Tuomenvirta, H., Werner, P.C., Linderholm, H., Philipp, A., Wanner, H., and Xoplaki, E.: Indices for daily temperature and precipitation extremes in Europe analyzed for the period 1901-2000, J. Geophys. Res.-Atmos., 111, D22106, doi:10.1029/2006JD007103, 2006.

National Center for Atmospheric Research (NCAR): Model Evaluation Tools version 4.1 (METv4.1): User's guide 4.1. Developmental Testbed Center Rep., 226 pp., available at:
http://www.dtcenter.org/met/users/docs/users_guide/MET_ Users_Guide_v4.1.pdf (last access: 19 April 2017), 2013.

Parodi, A., Boni, G., Ferraris, L., Siccardi, F., Pagliara, P., Trovatore, E., Foufoula-Georgiou, E., and Kranzlmueller, D.: The "perfect storm": From across the Atlantic to the hills of Genoa, EOS T. Am. Geophys. Un., 93, 225-226, 2012.

Pasquaré, F. A. and Oppizzi, P.: How do the media affect public perception of climate change and geohazards? An Italian case study, Global Planet. Change, 90, 152-157, 2012.

Pieri, A. B., von Hardenberg, J., Parodi, A., and Provenzale, A.: Sensitivity of Precipitation Statistics to Resolution, Microphysics, and Convective Parameterization: A Case Study with the High-Resolution WRF Climate Model over Europe, J. Hydrometeorol., 16, 1857-1872, 2015.

Pinto, J. G., Ulbrich, S., Parodi, A., Rudari, R., Boni, G., and Ulbrich, U.: Identification and ranking of extraordinary rainfall events over Northwest Italy: The role of Atlantic moisture, J. Geophys. Res.-Atmos., 118, 2085-2097, 2013.

Reale, O., Feudale, L., and Turato, B.: Evaporative moisture sources during a sequence of floods in the Mediterranean region, Geophys. Res. Lett., 28, 2085-2088, 2001.

Rebora, N., Molini, L., Casella, E., Comellas, A., Fiori, E., Pignone, F., Siccardi, F., Silvestro, F., Tanelli, S., and Parodi, A.: Extreme rainfall in the mediterranean: what can we learn from observations?, J. Hydrometeorol., 14, 906-922, 2013.

Rodrigo, F. S.: Changes in the probability of extreme daily precipitation observed from 1951 to 2002 in the Iberian Peninsula, Int. J. Climatol., 30, 1512-1525, 2010.

Schumacher, R. S. and Johnson, R. H.: Organization and environmental properties of extreme-rain-producing mesoscale convective systems, Mon. Weather Rev., 133, 961-976, 2005.

Silvestro, F., Rebora, N., Giannoni, F., Cavallo, A., and Ferraris, L.: The flash flood of the Bisagno Creek on 9th October 2014: An "unfortunate" combination of spatial and temporal scales, J. Hydrol., 541, 50-62, 2015.

Silvestro, F., Rebora, N., Rossi, L., Dolia, D., Gabellani, S., Pignone, F., Trasforini, E., Rudari, R., De Angeli, S., and Masciulli, C.: What if the 25 October 2011 event that struck Cinque Terre (Liguria) had happened in Genoa, Italy? Flooding scenarios, hazard mapping and damage estimation, Nat. Hazards Earth Syst. Sci., 16, 1737-1753, doi:10.5194/nhess-16-17372016, 2016.

Skamarock, W. C., Klemp, J. B., Dudhia, J., Gill, D. O., Barker, D. M., Duda, M. G., Xiang-Yu, Wang, W., and Powers, J. G.: A Description of the Advanced Research WRF Version 3 (No. NCAR/TN-475+STR), National Center for Atmospheric Research Boulder, Mesoscale and Microscale Meteorology Division, 2008.

Squitieri, B. J. and Gallus Jr., W. A.: WRF Forecasts of Great Plains Nocturnal Low-Level Jet-Driven MCSs. Part II: Differences between Strongly and Weakly Forced Low-Level Jet Environments, Weather Forecast., 31, 1491-1510, 2016.

Stucki, P., Brönnimann, S., Martius, O., Welker, C., Rickli, R., Dierer, S., Bresch, D. N, Compo, G. P., and Sardeshmukh, P. D.: Dynamical downscaling and loss modeling for the reconstruction of historical weather extremes and their impacts: a severe Foehn storm in 1925, B. Am. Meteorol. Soc., 96, 1233-1241, 2015.

TechnicalInfo: WRF version 3.4.1 namelist.wps and namelist.input used to perform the 56 members ensemble simulations 
for the period 24 september 191512 UTC-26 september 1915 00UTC using the 20th Century Reanalysis data V2C, doi:10.23728/b2share.d11a972cf2f944b6be2f5f94d9d9be0a, 2017.

Thompson, G., Field, P. R., Rasmussen, R. M., and Hall, W. D.: Explicit forecasts of winter precipitation using an improved bulk microphysics scheme. Part II: Implementation of a new snow parameterization, Mon. Weather Rev., 136, 5095-5115, 2008.

Toreti, A., Xoplaki, E., Maraun, D., Kuglitsch, F. G., Wanner, H., and Luterbacher, J.: Characterisation of extreme winter precipitation in Mediterranean coastal sites and associated anomalous atmospheric circulation patterns, Nat. Hazards Earth Syst. Sci., 10, 1037-1050, doi:10.5194/nhess-10-1037-2010, 2010.

Toreti, A., Giannakaki, P., and Martius, O.: Precipitation extremes in the Mediterranean region and associated upper-level synopticscale flow structures, Clim. Dynam., 47, 1-17, 2015.

Trenberth, K. E.: Changes in precipitation with climate change, Clim. Res., 47, 123-138, 2011.

Trouet, V. and Van Oldenborgh, G. J.: KNMI Climate Explorer: a web-based research tool for high-resolution paleoclimatology, Tree-Ring Res., 69, 3-13, 2013.

Ulbrich, U., Lionello, P., Belušić, D., Jacobeit, J., Knippertz, P., Kuglitsch, F. G., Leckebusch, G. C., Luterbacher, J., Maugeri, M., Maheras, P., Nissen, K. M., Pavan, V., Pinto, J. G., Saaroni, H., Seubert, S., Toreti, A., Xoplaki, E., and Ziv, B.: Climate of the Mediterranean: synoptic patterns, temperature, precipitation, winds, and their extremes. In The Climate of the Mediterranean Region-From the Past to the Future, Elsevier, London, 2012.
Van den Besselaar, E. J. M., Klein Tank, A. M. G., and Buishand, T. A.: Trends in European precipitation extremes over 1951-2010, Int. J. Climatol., 33, 2682-2689, 2013.

Violante, C., Braca, G., Esposito, E., and Tranfaglia, G.: The 9 September 2010 torrential rain and flash flood in the Dragone catchment, Atrani, Amalfi Coast (southern Italy), Nat. Hazards Earth Syst. Sci., 16, 333-348, doi:10.5194/nhess-16-333-2016, 2016.

Ward, P. J., Jongman, B., Weiland, F. S., Bouwman, A., van Beek, R., Bierkens, M. F. P., Ligtvoet, W., and Winsemius, H. C.: Assessing flood risk at the global scale: model setup, results, and sensitivity, Environ. Res. Lett., 8, 044019, doi:10.1088/17489326/8/4/044019, 2013.

Whitaker, J. S., Compo, G. P., Wei, X., and Hamill, T. M.: Reanalysis without radiosondes using ensemble data assimilation, Mon. Weather Rev., 132, 1190-1200, 2004.

Yair, Y., Lynn, B., Price, C., Kotroni, V., Lagouvardos, K., Morin, E., Mugnai, A., and Llasat, M. d. C.: Predicting the potential for lightning activity in Mediterranean storms based on the Weather Research and Forecasting (WRF) model dynamic and microphysical fields, J. Geophys. Res.-Atmos., 115, D04205, doi:10.1029/2008JD010868, 2010. 